REJ - Revista de Estudios de la Justicia - No 10 - Año 2008

\title{
ALGUNOS ASPECTOS PROCESALES DE LA LEY N 18.216
}

\author{
Juan Carlos Marín Gonzáleż
}

Introducción; I. Evolución del recurso de casación (forma y fondo) en relación con la ley 7.821 y la ley 18.216. (1906-2002); II. Evolución del recurso de apelación en relación con la aplicación de la ley 18.216; III. Evolución del recurso de queja en relación con la aplicación de las leyes 7.821 y 18.216; IV. El recurso de nulidad (2000-2006): sigue la senda del recurso de casación y del de queja.

\section{Introducción*}

1.- En este trabajo analizaré algunos aspectos procesales de la ley 18.216, sobre medidas alternativas a las penas privativas o restrictivas de libertad. Principalmente me concentraré en precisar si la resolución judicial que se pronuncia sobre dichas medidas — sea para concederlas sea para denegarlas- es susceptible de ser impugnada a través de algún mecanismo procesal. En la medida que la respuesta judicial a esta interrogante - lo adelanto- es negativa, también aportaré de lege lata nuevos elementos de interpretación que puedan dar una nueva luz en esta materia.

2.- La ley 18.216 — publicada en el Diario Oficial el 14 de mayo de 1983 encuentra su antecedente más directo en la ley 7.821, de 29 de agosto de 1944, sobre suspensión de la ejecución de la sanción impuesta en la sentencia condenatoria. Esta última legislación, por su parte, fue modificada por la ley 17.642, de 4 de mayo de 1972, con la finalidad de corregir algunos vicios que tras casi 30 años de aplicación se evidenciaban en la práctica judicial chilena.

3.- El análisis de ley 18.216 y de sus antecedentes históricos, nos muestran que fruto de la unión de dos circunstancias diversas, por un lado, una estricta interpretación que a propósito del recurso de casación desarrolló el máximo tribunal nacional (explicaré esta situación en el apartado II de este estudio) y, por el otro, las distintas reformas que en los últimos lustros se han acometido a

\footnotetext{
- Juan Carlos Marín G. Doctor en Derecho. Profesor e investigador del Centro de Estudios de la Justicia (CEJ), Facultad de Derecho, Universidad de Chile. Profesor de derecho procesal Universidad Adolfo Ibáñez.

* Este trabajo es fruto de un informe requerido por la Defensoría Penal Pública. Agradezco a dicha Institución todo el apoyo brindado para su realización, en especial a Cristián Arias Vicencio y al personal de su unidad. Agradezco, asimismo, las facilidades dadas para la publicación del mismo. Tuve, además, en la recolección de los materiales la valiosa colaboración de los ayudantes de la Facultad de Derecho de la Universidad de Chile señores Lucas MacClure y de Adrián Schofp. Una versión preliminar de este documento fue objeto de lúcidos comentarios de los profesores de la misma casa de estudios señores Miguel Soto y Jonatan Valenzuela. A todos mis sinceros agradecimientos.
} 
nuestro ordenamiento procesal, se llegó a un escenario paradójico que, creo, no se buscó conscientemente: la sentencia definitiva condenatoria del tribunal de juicio oral en lo penal que concede o deniega alguna de las medidas alternativas reguladas en la ley 18.216 — remisión condicional de la pena, reclusión nocturna y libertad vigilada - no es susceptible de ulterior revisión.

4.- A esta situación se arribó, como indiqué, en primer término debido a una estricta interpretación que, al menos desde fines de los años sesenta, desarrolló la Corte Suprema al declarar inadmisibles los recursos de casación en la forma y en el fondo - existentes bajo el anterior sistema de enjuiciamiento criminal en Chile- con los cuales se impugnaba la sentencia condenatoria de segunda instancia que no había concedido (o había concedido erróneamente) alguna de las medidas alternativas previstas, primero, en la ley 7.821, y más tarde, en la ley 18.216. Esta interpretación ha sido reiterada — sin mayor cuestionamiento- a propósito del recurso de nulidad bajo el actual sistema procesal penal, según lo veremos más adelante.

5.- El segundo elemento decisivo para arribar a esta paradojal situación fue una serie de reformas legislativas que eliminaron, sucesivamente, los otros dos recursos a los que habitualmente se acudía para impugnar la sentencia condenatoria — de primera o segunda instancia— que debía pronunciarse sobre la aplicación de alguna medida alternativa a la privación de la libertad: el recurso apelación, primero, y el de queja, posteriormente. Sobre estos temas volveré, respectivamente, en los apartados III y IV de este trabajo.

\section{Evolución del recurso de casación (forma y fondo) en relación con la ley 7.821 y la ley 18.216. (1906-2002).}

Para arribar a la uniformidad referida en el número cuatro precedente, la Corte Suprema ha recorrido un camino que es bueno conocer. Él nos dará luces sobre otras interpretaciones que, en su momento, también realizó nuestro máximo tribunal y que, ahora, con mejores herramientas normativas, podría ser retomada por algunos ministros de nuestros tribunales superiores de justicia. Didácticamente, he divido esta evolución en cinco fases.

1.1. Primera época: (1906-1944). Este período comprende desde la fecha en que se publicó el Código de Procedimiento Penal (CPP 1906), y el año en que entró en vigor la ley 7.821, sobre remisión condicional de la pena. El referido Código en su artículo 603 original — posteriormente artículo 564 sancionó, en relación con las penas de faltas, la primera norma que permitía a los jueces chilenos suspender hasta por tres años la aplicación dichas penas. Dispuso la aludida normativa:

Si resultare mérito para condenar por faltas a un reo contra quien nunca se hubiere pronunciado condenación, el juez le impondrá la pena que 
REJ - Revista de Estudios de la Justicia - No 10 - Año 2008

corresponda; pero, si aparecen antecedentes favorables, podrá dejarla en suspenso hasta por tres años, declarándolo en la sentencia misma, y apercibiendo al reo para que se enmiende». Agregaba en el inciso segundo que: «Si dentro de ese plazo, éste reincidiere, el fallo que se dicte en el segundo proceso lo condenará a cumplir la pena suspendida y la correspondiente a la nueva falta, simple delito o crimen de que se le juzgue culpable».

En esta disposición - pese a su acotado campo de acción- se encuentra el germen de la que posteriormente se denominaría, genéricamente, remisión condicional de la pena y que, cuarenta años más tarde, recogería nuestro legislador de modo amplio en la ley $7.821^{1}$. La aludida disposición encuentra su origen en la denominada Comisión Mixta de Senadores y Diputados, que informó sobre el Proyecto de Código de Procedimiento Penal el año 1902.

En efecto, en la sesión número 23, de 16 de junio de 1902, al ponerse en discusión el Libro Tercero, de los procedimientos especiales, y en concreto, a la luz del procedimiento en materia de faltas, una vez aprobado por los comisionados el artículo 625 del Proyecto — relativo al plazo para apelar y/o casar la sentencia definitiva- el comisionado Barros Méndez llamó

[1] a atención a los resultados, en realidad admirables, que se han obtenido en Francia, Inglaterra, y sobretodo en Bélgica, con el sistema de penas condicionales a los reos que delinquen por primera vez, y cree que también podría introducirse en nuestra legislación un sistema semejante, siquiera por vía de ensayo en materia de faltas, ya que no hay razón para pensar que no produzca entre nosotros análogos resultados. [...] Cree que este sistema de condenas condicionales habrá de traer como lógica consecuencia la disminución de los detenidos y, con ello, una importante economía para el tesoro público. Sostiene que la permanencia pasajera en una prisión no puede estimarse como un medio práctico de regeneración o enmienda y sí puede ser dañosa para los que posean sentimientos de honor y dignidad personales. Por otra parte, hay un interés público en reducir el rol de la prisión a aquellos para quienes sea indispensable, puesto que sabido es que la cárcel desgasta el fondo de honradez y dignidad de los ciudadanos. Fundados en consideraciones de esta índole los tratadistas modernos tratan de restablecer más debajo de la escala de las penas, la admonición y las sentencias condicionales, como medidas adecuadas para los grados inferiores de la criminalidad. Estima seguro que

\footnotetext{
${ }^{1}$ Con anterioridad al año 1944, encontramos otro antecedente en esta materia en la ley 6.827 de 14 de febrero de 1941, sobre organización y atribuciones de los Juzgados de Policía Local, que en su artículo 24 inc. $1^{\circ}$ señaló: «Si resultare mérito para condenar a un infractor que no hubiere sido antes sancionado, el juez le impondrá la pena correspondiente, pero si aparecen antecedentes favorables, podrá dejarla en suspenso hasta 3 meses, declarándolo en la sentencia misma y apercibiendo al infractor para que se enmiende». (La cursiva es mía).
} 
aplicando con conciencia y discernimiento este régimen en los casos en que se establezca, opondrá a las reiteraciones un freno más poderoso que la molestia pasajera producida por la prisión ${ }^{2}$.

Luego de discutir los comisionados cuál debía ser el lugar apropiado para este tipo de iniciativa —el presente Código o una ley sustantiva especial—, todos estuvieron de acuerdo en que de no poderse incluir en el Proyecto, sería altamente conveniente consultarlo en un proyecto de ley separado. Se dejó, por tanto, pendiente de estudio la indicación del comisionado Barros Méndez.

En la sesión siguiente, esto es, en la número 24, de 20 de junio de 1902, el señor Barros Méndez concretó la indicación que formuló en la reunión anterior sobre la pena condicional, y propuso a continuación del artículo 625 un nuevo numeral. Al respecto agregó que: «En rigor, no puede estimarse esta disposición como una materia extraña al procedimiento, ya que en realidad determina la forma en que debe darse cumplimiento a la sentencia; y por esta razón, ha indicado que se la agregue después del artículo 625 que trata de su ejecución». Luego de un breve debate la comisión aprobó el siguiente nuevo artículo:

Art. ... Si resultare mérito para condenar por faltas a un reo contra quien nunca se hubiere pronunciado condenación, el juez le impondrá la pena que corresponda; pero, si aparecieren antecedentes favorables, podrá dejarla en suspenso hasta por tres años, declarándolo en la sentencia misma, y apercibiendo al reo para que se enmiende.

$\mathrm{Si}$, dentro de ese plazo, éste reincidiere, el fallo que se dicte en el segundo proceso lo condenará a cumplir la pena suspendida y la que corresponda a la nueva falta, simple delito o crimen de que se le juzgue culpable ${ }^{3}$.

De allí que en el informe que emitió la aludida Comisión Mista al Senado de la República, se haya señalado sobre este particular lo siguiente:

La pena, reparación del mal causado por el delito, puede ser suplida, con ventaja de la sociedad, por la enmienda del culpable; suspenderla mientras éste no reincida es un medio para procurar que se corrija, practicado en algunos países. Esperando que más tarde sea de uso general entre nosotros, la Comisión lo propone autorizando al juez para suspender la pena de faltas a reos condenados por primera vez, previa una amonestación de que no vuelvan a delinquir y la declaración de que si delinquieren de nuevo, habrán de padecer también aquella ${ }^{4}$.

\footnotetext{
2 Actas de la Comisión Mista de Senadores y Diputados, encargada de informar sobre el Proyecto de Código de Procedimiento Penal, Santiago, 1902, págs. 376 y 377.

3 Ídem, págs. 382-384.

4 Proyecto de Código de Procedimiento Penal, revisado por la Comisión Mista de Senadores y Diputados, Santiago, 1902, págs. XIV y XV.
} 
El deseo de nuestros legisladores, por tanto, fue que esta suspensión pudiera ser más adelante de uso general en el ámbito criminal chileno. Como sabemos, lo anterior sólo se concretó 40 años después. Más allá del tiempo que tardó en generalizarse esta institución, deseo destacar que el legislador nacional previó desde un comienzo que la declaración de suspensión fuese realizada en la sentencia condenatoria misma; no en una resolución diversa, ni en un anexo de la misma, mostrando inequívocamente la ligazón que existe entre, por un lado, la decisión sobre la condena de un sujeto, y, por el otro, la manera cómo dicho sujeto va a cumplir la condena impuesta. En palabras de Barros Méndez, porque en rigor no puede estimarse esta disposición como una materia extraña al procedimiento. Incluso en esos años se hablaba derechamente de una condena o pena condicional para referirse a esta suspensión.

Ahora bien, pese a que en este primer período se publicaron pocos fallos que dieran aplicación directa a esta disposición, hay algunos que son interesantes porque esbozan una tendencia que después será mayoritaria en nuestra jurisprudencia. El primer fallo que hemos localizado se refiere al delito de expender aguardiente clandestinamente, en el cual se condenó a la denunciada a pagar $\$ 100$ de multa, y si no tuviere dinero «a un día de prisión por cada $\$ 10 »$. Agregó la sentencia condenatoria de primera instancia: «Y, teniendo presente, que a favor de la condenada militan los antecedentes favorables de su espontánea confesión y de no haber sido condenada anteriormente, de acuerdo con lo previsto en el artículo 603 del cuerpo de leyes más arriba citado, se deja en suspenso el cumplimiento de esta condena por el término de 3 años y se apercibe a doña $[\ldots]$ para que se enmiende».

La Corte de Apelaciones, sin embargo, interpretó que se trataba de una infracción a la ley de alcoholes y que, por tanto, no procedía la suspensión. De este modo, revocó en esta parte la sentencia de primera instancia y señaló:

[L]a facultad que confiere el artículo 603 del Código de Procedimiento Penal, a los jueces, para dejar en suspenso hasta por 3 años la pena impuesta a un inculpado contra quien nunca se hubiere pronunciado condenación, sólo se refiere a los casos en que resultase del proceso mérito suficiente para condenar por falta; y que atendido el monto de la multa $[. .$.$] a la infracción que ha motivado este proceso, no es del caso$ considerar dicha infracción como una simple falta, y, por tanto, no le es aplicable la disposición mencionada en el considerando precedente ${ }^{5}$.

Si bien no estamos frente a un recurso de casación, cito esta resolución para destacar que los jueces nacionales desde un comienzo interpretaron que se encontraban frente a una facultad - la cual podían aplicar sin mayor justificación- más que en presencia de un verdadero derecho del condenado.

\footnotetext{
${ }^{5}$ Gaceta de los Tribunales, 1935, 1er. semestre, No 110, págs. 542 y 543.
} 
Esta será una idea muy perniciosa en toda la evolución posterior de esta institución. Lógicamente a esto también contribuyó el vocablo podrá que empleó el legislador nacional, así como lo tímido que fue a la hora de introducir este tipo de medidas en el ordenamiento procesal chileno. (Más adelante veremos que la historia de la ley 7.821 también va a confirmar esta interpretación).

El segundo proceso que vamos a analizar también dice relación con una infracción de la ley de alcoholes. Tiene gran interés porque aquí hay un pronunciamiento expreso de la Corte Suprema frente a un recurso de casación en la forma. Al igual que en el primer caso, en este segundo se condenó al imputado en primera instancia a pagar a título de pena una multa de $\$ 100$. Apelada dicha resolución la Corte respectiva confirmó el fallo, con declaración que «se suspendía la aplicación de la pena impuesta por el juez de primera instancia, por el término de 6 meses, apercibiéndose a la infractora para que se enmiende para que no vuelva a incurrir en igual falta».

En contra de esta sentencia la Defensa Fiscal de la Ley de Alcoholes dedujo recurso de casación en la forma, que hizo consistir, en el punto de la suspensión de la pena, en haber sido dada ultra petita, esto es, extendiéndola a puntos inconexos con los que fueron materia de la acusación o la defensa. La Defensa Fiscal argumentó que al haberse declarado por la Corte que se suspendía la aplicación de la pena impuesta por el término de 6 meses y al hacerse la prevención que en ella se indica,

[S]e hace una declaración que no fue materia de la defensa. Esta facultad que la ley concede al Tribunal sólo puede ejercitarse en casos muy calificados y a petición de parte, pero no puede transformarse en una medida que el Tribunal pueda otorgar de oficio». Añade, en su alegato, que en el presente proceso: "La declaración de que se trata no procedía por cuanto la única cuestión debatida fue, si la denunciada era o no responsable de la infracción que se le imputaba en el parte de Carabineros. La calificación legal de esa infracción no fue discutida". Termina su escrito señalando que "al hacerse la prevención aludida se ha hecho una declaración en única instancia que no tiene atingencia con el punto plantado en el proceso".

Los argumentos de la Defensa Fiscal se centraron directamente en un punto que, muchos años después, la Corte Suprema recogería para desechar los recursos de casación en la forma y en el fondo, a saber, que la decisión judicial que se pronuncia sobre las medidas alternativas a las penas es ajena a la sentencia condenatoria misma, porque no resuelve sobre el hecho punible ni sobre la participación. Pero el año 1937 la Corte Suprema pensaba otra cosa:

Que el tribunal sentenciador al disponer la suspensión de la pena impuesta [...] por el término de 6 meses, ejerció una facultad discrecional que le confiere el artículo 603 del Código de Procedimiento Penal; al hacer esa 
declaración en la sentencia, no comprende en ella una materia extraña a la infracción que se castiga ni al procedimiento del pleito, sino que determina en realidad la manera cómo debe cumplirse lo fallado, para lo cual no necesita petición de parte; Que, en consecuencia, no hay en la sentencia que se reclama una decisión ajena a la cuestión que fue materia del proceso y mucho menos se extiende a puntos inconexos con los que fueron materia de la acusación y de la defensa, circunstancias que constituyen el vicio de ultra petita. [...] En mérito de estas consideraciones [...] se declara sin lugar el recurso de casación interpuesto por la Defensa Fiscal de la ley de Alcoholes, en contra de la sentencia de 27 de agosto último, corriente a fojas $9^{6}$.

Es destacable que en 1937 la Corte Suprema haya tenido la claridad de señalar que los aspectos relativos a la suspensión de la pena no son ajenos a la sentencia condenatoria misma. De este modo, en ese año, rechazó la postura de la Defensa Fiscal en cuanto a que la sentencia de segunda instancia, al ordenar la suspensión de la pena de oficio, efectuó una declaración que no fue materia de la defensa y que, por tanto, no correspondía realizar porque la única cuestión debatida fue si la denunciada era o no responsable de la infracción que se le había imputado. Frente a esta pretensión, la Corte expresa que al hacer esa declaración en la sentencia, no se comprende en ella una materia extraña a la infracción que se castiga, ni al procedimiento del pleito, sino que determina en realidad la manera cómo debe cumplirse lo resuelto. Nuestro máximo tribunal es categórico en cuanto a resolver que en la sentencia impugnada no hay ninguna decisión ajena a la cuestión que fue materia del proceso, y mucho menos se extiende ella a puntos inconexos con los que fueron materia de la acusación y de la defensa.

1.2. SEgUNDA ÉPOCA: (1944-1953). El período comprende desde la fecha en que se publicó la ley 7.821 y el primer fallo de la Corte Suprema que trató directamente el asunto regulado en dicha ley. En este período, salvo el fallo recién aludido, no aparecen en la Revista de Derecho y Jurisprudencia ni en la Gaceta de los Tribunales —únicas publicaciones especializadas en esos años-, algún fallo que en grado de casación trate directamente esta situación. Es razonable pensar que la implementación misma de esta breve ley (contenía sólo cuatro artículos) y la duración de los procesos judiciales hubiesen retardado su conocimiento por los tribunales superiores del país. No debe descartarse, en todo caso, la circunstancia de que las personas encargadas de seleccionar los fallos no hubieren prestado mayor atención a este punto.

En el mensaje con el cual se presentó el proyecto de ley, que daría origen a la ley 7.821, se indicó que el referido proyecto había sido preparado por el Instituto de Ciencias Penales, y que: «Es de la esencia de la institución sobre la

\footnotetext{
${ }^{6}$ Gaceta de los Tribunales, 1937, 2 . semestre, No 130, págs. 540 y 541. Corte Suprema, 14 de diciembre de 1937, integrada por señores ministros: C. Alberto Novoa, Romilio Burgos, Gregorio Schepeder, Mariano Fontecilla y Roberto Peragallo.
} 
cual versa el proyecto, su carácter eminentemente facultativo toda vez que serán los tribunales de Justicia — sean los de primera o de segunda instancia- los llamados a resolver en cada caso concreto sometido a su decisión y en atención al estudio que deberá hacer de la personalidad del condenado, si procede o no dejar en suspenso la ejecución de la sanción que hubiere de imponerle la respectiva sentencia condenatoria. A ello se debe la forma de redacción de los artículos primero y segundo del proyecto»?

Como se aprecia, el legislador de manera más bien tímida justifica esta importante institución, dándole el calificativo de medida eminentemente facultativa. De esta forma corrobora y avala una interpretación que los jueces nacionales, según lo hemos mencionado, ya habían hecho suya y que en el futuro desarrollarán extensamente.

En relación con la forma cómo los tribunales debían conceder este beneficio, el referido mensaje señaló:

Con el objeto de evitar arbitrariedades el artículo segundo del proyecto exige que el Tribunal que determine la imposición de la pena y que considere pertinente su remisión condicional, deberá así resolverlo en la respectiva sentencia condenatoria, expresando circunstanciadamente los fundamentos que ha tenido presente para hacerlo. Lógicamente, dichos Tribunales nada dirían si no juzgan del caso remitir condicionalmente la pena ${ }^{8}$. (El destacado es nuestro)

En el informe de la Comisión de Constitución, Legislación y Justicia, de la H. Cámara de Diputados, se reiteró esta idea: «Se exige en el proyecto que si el tribunal de primera o de segunda instancia estima procedente suspender la ejecución de la sanción que imponga la sentencia condenatoria, así deberá expresarlo en ella, determinando los fundamentos en que se apoya»?

Esta circunstancia es importante tenerla presente, porque si bien la ley 7.821 le otorgó a esta institución un carácter eminentemente facultativo, agregó de inmediato que para evitar arbitrariedades en la decisión, el tribunal que concedía la suspensión —en primera o segunda instancia - debía señalar circunstanciadamente los fundamentos tenidos en cuenta para hacerlo. Es decir, de acuerdo al adverbio empleado, el tribunal debía razonar sin omitir ninguna circunstancia o particularidad, de tal forma que la concesión de este beneficio estuviere siempre debidamente fundada. Como se comprenderá, esta fue la forma cómo el legislador diseñó un adecuado control de las resoluciones de los jueces de primera o segunda instancia. Una errónea fundamentación - dependiendo del tribunal que la hubiere realizado-, permitiría su revocación a través del recurso de apelación o casación,

\footnotetext{
7 Senado de Chile, Sesión 5a. Ordinaria, martes 6 de junio de 1944, pág. 263.

8 Senado de Chile, Sesión 5a. Ordinaria, martes 6 de junio de 1944, pág. 263.

${ }^{9}$ Cámara de Diputados, Sesión 25a . Ordinaria, del 11 de julio de 1944, pág. 981.
} 
REJ - Revista de Estudios de la Justicia - No 10 - Año 2008

según correspondiere. Bajo este respecto, fue lamentable que estas razones sólo se hayan exigido al momento de conceder el beneficio, y no en el caso inverso, esto es, frente a su negativa. Como se señaló en el aludido mensaje «[...] lógicamente, dichos Tribunales nada dirían si no juzgan del caso remitir condicionalmente la pena». Esta situación se enmendó recién el año $1972^{10}$.

El año 1953 la Corte Suprema se pronunció, como hemos avanzado, por primera vez sobre la aplicación de la ley 7.821 conociendo de un recurso de casación en la forma. Se recurría en contra de la sentencia de segunda instancia (que hizo suyo el fallo de primera) que prescindió de la solicitud de remisión condicional de la pena hecha al contestarse la acusación. En aquella ocasión señaló el tribunal:

Que si bien se hace valer, como se ha dicho, el $\mathrm{N}^{\circ} 3$ del artículo 500, es lo cierto que el fundamento de la nulidad consiste, no en haberse omitido en la parte expositiva lo relativo a la solicitud de remisión, omisión que no existe, sino en no contener el fallo las "consideraciones para negar o acoger la remisión de la pena"; pero este hecho, por incongruente con el antecedente legal invocado, y por no ser constitutivo de la causal en referencia, no da mérito para acoger el recurso ${ }^{11}$.

En este considerando la Corte estableció correctamente el punto medular de la discusión: «No contener el fallo las consideraciones para negar o acoger la remisión de la pena», pero al estimar que la causal invocada por el recurrente no era la correcta, desechó el motivo de casación. Aquí se perdió una primera oportunidad de interpretar la naturaleza de la suspensión contenida en la ley 7.821.

Más adelante se agrega en el fallo que comentamos:

Que en verdad, si algún agravio hubiera para el reo en la sentencia en relación con el punto en debate, él no sería otro que el no haberse acogido su solicitud de remisión, circunstancia no constitutiva de un vicio de nulidad, puesto que el $\mathrm{N}^{\circ} 7$ del artículo 500 ya citado sólo impone al

10 De este modo, la ley 7.821, en lo que ahora nos interesa, estableció primitivamente como requisitos de procedencia de la remisión condicional de la pena los siguientes artículos. Artículo $1^{\circ} .:$ «Sin perjuicio de lo dispuesto en el artículo 603 del Código de Procedimiento Penal, los Tribunales podrán suspender la ejecución de la sanción que imponga la sentencia condenatoria, cuando concurran los siguientes requisitos: a) Que la sentencia aplique una pena restrictiva o privativa de la libertad que no exceda de un año; b) Que el reo no haya sido condenado anteriormente por crimen o simple delito, y; c) Que los antecedentes personales del reo y su conducta anterior, la naturaleza, modalidades y móviles determinantes del delito permitan presumir que no volverá a delinquir». Por su parte, el artículo $2^{\circ}$. dispuso lo siguiente: «Si el Tribunal de primera o de segunda instancia, estima procedente hacer uso de la facultad establecida en el artículo anterior, deberá así ordenarlo en la respectiva sentencia condenatoria, expresado circunstancialmente los fundamentos en que se apoya [...]». (Las cursivas son mías).

${ }^{11}$ RDJ, t. L (1953), 2a . parte, sección cuarta, pág. 30. 
tribunal la obligación de pronunciarse acerca de la "condena o absolución de cada uno de los reos, sobre la responsabilidad de los mismos o de terceros comprendidos en el juicio y sobre el monto de las indemnizaciones cuando se las haya pedido y se dé lugar a ellas". Suspender o no el cumplimiento de la pena es facultad exclusiva de los tribunales y las partes no pueden obligarlos a hacer un pronunciamiento al respecto. El silencio en el ejercicio de esta potestad, aunque la parte la impetre, no autoriza la nulidad.

Que, en efecto, el artículo $2^{\circ}$ de la Ley 7.821 dispone "que si el tribunal de primera o de segunda instancia estima procedente hacer uso de la facultad establecida en el artículo anterior, deberá así ordenarlo en la respectiva sentencia condenatoria, expresando circunstancialmente los fundamentos en que se apoya". El silencio de la ley en orden a las razones que deberían expresarse cuando los tribunales no estiman pertinente otorgar el beneficio en debate, manifiesta que en tal caso es innecesario un pronunciamiento ${ }^{12}$.

Como vemos, el punto de debate se desplaza desde la necesidad de fundamentar debidamente la concesión o el rechazo de la suspensión, por el de no haberse acogido la solicitud de suspensión. Y en este punto, nuestro máximo tribunal maneja dos argumentos diversos para desechar el recurso, uno de los cuales - el segundo- estaba zanjado normativamente. Así, en primer término, perfila la idea de que el pronunciamiento relativo a la remisión condicional de la pena es ajeno a los requisitos de la sentencia definitiva misma (art. $500 \mathrm{~N}^{\circ} 7 \mathrm{del}$ CPP, 1906). En segundo lugar, que suspender o no el cumplimiento de la pena es una facultad exclusiva de los tribunales, respecto del cual las partes no pueden obligarlos a hacer un pronunciamiento. En este sentido, ya sabemos que el artículo 2 de la Ley 7.821 sólo obligaba a los tribunales de instancia a fundar circunstancialmente la procedencia de la suspensión de la pena pero no su rechazo. Con lo cual la Corte estimó que el silencio de la ley, esto es, el no haber dicho nada para la eventual negativa del beneficio, autorizaba a los tribunales a denegarlo sin ningún fundamento.

1.3. Tercera Época: (1959-1972). Este período comprende desde el 12 de noviembre de 1959, tiempo en que se dicta la primera sentencia de nuestro máximo tribunal que anula una sentencia de segunda instancia que no fundamentó la revocación de la suspensión de la pena, hasta el año 1972, fecha en que se publica la ley 17.642, que introduce importantes adiciones a la ley 7.821. Él se caracteriza por un claro predominio del recurso de casación en la forma por sobre el de casación en el fondo. Si bien en algunos procesos este último aparece, normalmente no incide en el contendido de esta materia. Su principal rasgo lo denota el hecho de estar en presencia de sentencias bien fundadas, en el que cada

12 RDJ, t. L (1953), 2a . parte, sección cuarta, págs. 30 y 31. 
palabra aparece bien pensada. En este período abundan los argumentos en pos de una y otra tesis, con importantes votos de mayoría y minoría. Hacia el final de este ciclo, sin embargo, se nota una marcada decadencia en la manera de argumentar de nuestro máximo tribunal, quedando marcado el derrotero de nuestra jurisprudencia.

Tratándose de los fallos que rechazan la nulidad de la sentencia que no se pronunció sobre la suspensión de la pena o que no fundamentó su rechazo, se aprecia cierta confusión en los motivos que justifican esta decisión. En una suerte de síntesis, ellos pueden agruparse en tres motivos:

a) Los tribunales no están obligados a fundamentar el rechazo de este beneficio por lo que no procede anular la sentencia;

b) La suspensión o remisión condicional de la pena, por su naturaleza, no forma parte de las cuestiones que deben discutirse en el juicio y que se resuelven en la sentencia definitiva;

c) Es una facultad privativa de los juzgados de instancia no susceptible del recurso de casación.

Por el contrario, las razones dadas para acoger el recurso - sea en votos de mayoría o de minoría - discurren sobre la idea de que el contenido del artículo $2^{\circ}$ de la ley 7.821 integra la sentencia definitiva y, por lo tanto, su rechazo debe ser debidamente fundado, o porque su rechazo influye sustancialmente en lo dispositivo del fallo.

En 1959, nuestro máximo tribunal resolvió un recurso de casación en la forma que se interpuso en contra de la sentencia de alzada, que había revocado el beneficio de la suspensión de la pena concedido por el juez de primera instancia. En esta ocasión el fallo sostuvo lo siguiente:

Que se ha invocado como causal de casación en la forma la contemplada en el artículo $541 \mathrm{~N}^{\circ}$ 9, en relación con el artículo $500 \mathrm{~N}^{\circ} 4$ y 6 del Código de Procedimiento Penal, esto es, no haber sido extendida la sentencia, en la forma dispuesta por la ley y el vicio se lo hace consistir, en su primer aspecto, en que el fallo de segunda instancia omitió considerar las razones que tuvo en vista, para modificar el de primera, en cuanto a la remisión condicional de la pena impuesta al reo;

Que se trata pues, [habla de la remisión condicional] de una facultad privativa de los jueces de la instancia —que mientras no se ejercite, no es susceptible de originar formalidad alguna. No da lugar a exigencia de requisitos formales de ninguna especie; pero una vez ejercida $[\ldots] .{ }^{13}$

${ }^{13}$ RDJ, t. LVI (1959), 2ª parte, sección cuarta, pág. 268. 
La Corte sitúa el debate en sus justos términos, esto es, establece que se ha invocado como causal el no haberse extendido la sentencia en la forma establecida por la ley. El vicio reclamado consiste en que el fallo de segunda instancia omitió las razones que tuvo en vista para revocar el beneficio que había sido concedido en primera. Posteriormente, la Corte realiza una distinción algo confusa, aunque importante para la resolución del recurso: que el beneficio que se contiene en el artículo 2 de la ley 7.821 constituye una facultad privativa de los jueces de fondo, que mientras no se ejercite no es susceptible de casación. Aunque para mí no es claro qué significa esta última frase, la Corte parece discurrir sobre lo que a estas alturas constituía una situación relativamente estable en el foro nacional: que la suspensión constituye una facultad discrecional de los jueces de fondo. Pero de inmediato agrega y aquí viene el cambio más notable:

[...]; pero una vez ejercida, el asunto es bien diverso. En efecto, todo lo pertinente al beneficio se incorpora, íntegramente a la sentencia, y forma con ella un solo todo consubstancial. No se introduce, por este suceso, una cuestión accesoria o independiente, toda vez que el reo adquiere una situación de trascendencia, ligada a la condena, dado que la pena privativa de libertad queda expuesta a mantenerse en suspenso y hasta puede desaparecer con arreglo a lo dispuesto en el artículo $3^{\circ}$ de la mencionada ley ${ }^{14}$.

El fallo en comento tiene importantes elementos de interpretación que son perfectamente válidos el día de hoy. Continúa argumentando nuestro máximo tribunal:

Que como se ha visto, por mandato expreso del artículo $2^{\circ}$ de dicha ley, la sentencia condenatoria, condicionalmente expedida precisa un requisito nuevo, cual es, el de contener la expresión circunstanciada de los fundamentos en que se apoya, o dicho en otras palabras: las consideraciones en que se dan por comprobados los requisitos que enumera el artículo $1^{\circ}$. Por consiguiente; si los jueces se limitaran sólo a declarar suspendida la ejecución de lo resuelto, sin expresar los fundamentos en que se apoya, no podría sostenerse que la sentencia ha sido expedida en la forma dispuesta por la ley;

Que establecido como queda, que la sentencia que acuerde el beneficio de la suspensión de la pena, debe contener las consideraciones que le sirven de fundamento, ninguna razón se divisa para suponer que un fallo de segunda instancia que revoque, en esta parte el de primera, pueda omitir las consideraciones que correspondan para negar este beneficio. Se trata de requisitos formales, previstos por el artículo 500 del CPP, para las sentencias que modifiquen o revoquen las de otro tribunal. Y no debe

14 Ídem, págs. 268 y 269. 
olvidarse que el $\mathrm{N}^{\circ} 4$ del artículo 500, está complementado por las nuevas exigencias introducidas por el artículo $2^{\circ}$ de la referida ley ${ }^{15}$.

El punto clave de esta argumentación para anular el proceso y reponerlo al estado de dictarse nuevo fallo, fue entender que el artículo 500 del CPP —que señalaba los requisitos debía contener la sentencia definitiva- había sido complementado por el artículo $2^{\circ}$ de la Ley $7.821^{16}$, y que no había ninguna razón para entender que esta obligación no se aplicara también a los tribunales de alzada cuando revocaren el beneficio de la suspensión condicional de la pena ${ }^{17}$.

En 1960, en cambio, se desecha un recurso de casación en la forma interpuesto en contra de la sentencia de segunda instancia, que no se pronunció sobre la observación del fiscal de rebajar la pena del condenado y concederle la remisión de la condena «por reunirse los requisitos legales para ello». Si bien la sentencia de segunda instancia rebajó la pena, nada dijo en relación con la suspensión de la misma. La Corte Suprema estimó que debía desechar el recurso, porque la omisión de una simple «insinuación» del fiscal, no importa infracción del artículo $541 \mathrm{~N}^{\circ} 9$ en relación con el artículo 514, ambos del Código de Procedimiento Penal. Agregó la Corte que la remisión condicional de la pena no puede considerarse una observación que incida en las cuestiones debatidas en el proceso penal, ya que ello constituye el ejercicio de una facultad privativa que la ley $\mathrm{N}^{\mathrm{o}} 7.821$ concede al tribunal ${ }^{18}$.

El año 1963 será clave en el posterior desarrollo de esta institución. Este año se dictaron tres sentencias sobre la materia. El 7 de junio nuestra Corte Suprema, con muchas dudas, y con una redacción algo confusa, se inclinó por desechar el recurso. Lo notable de esta resolución fue que la Corte debido a los

15 Ídem, pág. 269.

${ }^{16} \mathrm{El}$ texto íntegro de esta disposición era del siguiente tenor: Artículo 2. «Si el Tribunal de primera o de segunda instancia, estima procedente hacer uso de la facultad establecida en el artículo anterior, deberá así ordenarlo en la respectiva sentencia condenatoria, expresado circunstancialmente los fundamentos en que se apoya. En tal caso, fijarán un plazo determinado de observación no inferior a un año, ni superior a tres, y establecerá las siguientes condiciones que el reo deberá cumplir: 1) Residencia en un lugar determinado, que podrá ser propuesto por el reo; 2) Sujeción a la vigilancia de alguno de los Patronatos de Reos, debiendo observar las normas de conducta que éste imparta; 3) Adoptar en un plazo fijo, que determinará el tribunal, profesión, oficio, empleo, arte, industria o comercio, si el reo no tiene medios conocidos y honestos de subsistencias, y 4) Satisfacer la responsabilidad civil, costas y multas impuestas por la sentencia. No obstante, el Tribunal, en caso de impedimento justificado, podrá acordar este beneficio aunque no se satisfagan la responsabilidad civil, costas y multas, sin perjuicio de que se hagan efectivas en conformidad a las reglas generales».

${ }^{17}$ Esta resolución de la Corte Suprema fue suscrita, entre otros, por el ministro Rafael Fontecilla R. y el abogado integrante Darío Benavente G.. Tuvo un importante voto de minoría suscrito por tres ministros.

${ }^{18}$ Fallos del Mes, № 16, págs. 10 y 11. 
problemas de interpretación que esta situación venía generando, eludió entrar en el problema de fondo:

Que sin entrar a examinar el problema relativo a la naturaleza jurídica de la resolución que accede o deniega la remisión condicional de la pena, la cual por mandato de la ley debe contenerse en la sentencia condenatoria misma, de todas maneras, debe advertirse que la consideración expresa y circunstanciada de los fundamentos en que se apoyó, conforme al artículo segundo de dicha ley, sólo hace referencia al otorgamiento de ese beneficio, que siempre es facultativo de los jueces de fondo, pero no al caso inverso de la no concesión o no ejercicio de la facultad, evento en el cual pueden, incluso, guardar silencio.

Agregando que: «[...] aun en el supuesto de que no hubiere obstáculos para impugnar una sentencia en la parte que hace referencia al uso de facultades privativas de los jueces de fondo, distintas de la materia propia de la litis, $y$ de que la sentencia de segunda instancia debiera necesariamente contener fundamentos para denegar la petición de remisión condicional, por tratarse de una remisión condicional, aunque no por el no uso de una facultad privativa, en todo caso — como se ha visto- el recurso no puede prosperar, porque el vicio que se imputa a la sentencia recurrida no existe en la realidad procesal del caso en análisis» ${ }^{19}$.

El 25 de octubre la Corte rechazó sendos recursos de casación en la forma y en el fondo, señalando que "tratándose de un beneficio que otorga una ley especial, como es la $\mathrm{N}^{\circ} 7.821$, lo que los tribunales dispongan a este respecto no forma parte de la sentencia recurrida en el respectivo recurso, en relación con el hecho delictivo que ha sido materia del mismo. Lo que se resuelve sobre este beneficio no tiene por qué ajustarse a las formalidades consignadas en el artículo 500 del CPP para las sentencias propiamente tales (casación en la forma), y que este beneficio no puede considerarse como una vulneración de la ley aludida (casación en el fondo) $»^{20}$.

Finalmente, el 6 de diciembre la Corte desechó un recurso de casación en el fondo con el cual se buscaba dejar sin efecto la medida de suspensión de la pena acordada en segunda instancia, porque el beneficio contenido en la Ley 7.821

$[\mathrm{N}]$ o dice relación con lo que es la sentencia propiamente tal y su parte dispositiva y, en consecuencia, la infracción de la ley que pudiere cometerse al remitirse condicionalmente la pena no tendría influencia en lo

${ }_{19}$ RDJ, t. LX (1963), 2 a parte, sección cuarta, págs. 264 y 265. También publicada en Fallos del Mes No 55 , pág. 105.

${ }^{20}$ RDJ, t. LX (1963), 2a . parte, sección cuarta, págs. 466 y 467. 
dispositivo del fallo y, por lo mismo debe desecharse el recurso de casación en el fondo $[. . .]^{21}$.

El año 1967 se recurrió de casación porque en opinión de la defensa la sentencia no había sido extendida «en la forma dispuesta por la Ley, pues el fallo no llenaría los requisitos de los números 4 y 7 del artículo 500 del Código de Procedimiento Penal al omitir todo pronunciamiento sobre la petición, formulada en el escrito en que se contestó la acusación, para que la pena le fuese remitida condicionalmente». En esta oportunidad la Corte señaló:

Que la Ley 7.821 faculta a los jueces para suspender la ejecución de la pena impuesta cuando concurren ciertos requisitos [...]; Que, como se ve, el ejercicio de esta atribución es totalmente ajeno a los requisitos que los N.os 4 y 7 del artículo 500 del Código de Procedimiento Penal establecen para la sentencia, pues la remisión condicional de la pena aplicada nada tiene que ver con la circunstancia de que el fallo contenga las consideraciones relacionadas con la prueba de los hechos atribuidos a los reos alegados por éstos en su descargo, ni con el deber del juez de resolver sobre la condena o absolución de los reos, su responsabilidad o las indemnizaciones que procedan. Se trata de una facultad privativa del juez encaminada a beneficiar, en ciertos casos, al reo ya condenado de acuerdo con la ley, suspendiendo la ejecución de la pena que le impuso, facultad que ejerce en forma soberana y que está en el deber de hacer constar y justificar en la sentencia, únicamente, cuando ha decidido hacer uso de ella a la resolución que se pronuncia sobre la remisión condicional de la pena, no forma parte de lo resolutivo de una sentencia, en lo que concierne a la controversia judicial que por ella se decide ${ }^{22}$.

Finaliza este período con dos fallos muy escuetos sobre la materia. El 26 de junio de 1967 se desecha el recurso de casación en la forma porque: «[...] la resolución que se pronuncia sobre la remisión condicional de la pena no forma parte de lo resolutivo de una sentencia, en lo que concierne a la controversia judicial que por ella se decide» ${ }^{23}$. Finalmente, 26 de junio de 1969 la Corte desecha un recurso de casación en el fondo, porque la infracción que se alega del artículo

\footnotetext{
${ }^{21}$ RDJ, t. LX (1963), 2a . parte, sección cuarta, pág. 571. También publicado en Fallos del Mes $\mathrm{N}^{\circ}$ 53, págs. 296 y 297. Este fallo tiene un importante voto de minoría del ministro J.M. Eyzaguirre quien, volviendo sobre la idea expresada por la Corte Suprema en 1959, sostuvo que: «[...] por disposición expresa del artículo $2^{\circ}$ de la ley 7.821 la resolución que declara haber lugar a la remisión condicional de la pena debe contenerse en la sentencia definitiva y, por tanto, esa resolución forma parte de tal sentencia ya que suspende condicionalmente lo que ella resuelve y la infracción que se comete al aplicar esa ley es una violación misma que influye en lo dispositivo del fallo». RDJ, t. LX (1963), $2^{\mathrm{a}}$. parte, sección cuarta, págs. 571 y 572.

22 RDJ, t. LXIV (1967), $2^{\text {a }}$. parte, sección cuarta, pág. 100.

${ }^{23}$ RDJ, t. LXIV (1967), 2a . parte, sección cuarta, pág. 160. También en Fallos del Mes No 103, págs. 132 y 133 .
} 
$1^{\circ}$ de la ley 7.821, sobre remisión condicional de la pena, confiere a los sentenciadores una facultad discrecional no sometida a la censura del tribunal de casación ${ }^{24}$.

Como puede apreciarse, pese a los buenos fallos que se dieron en este periodo, hacia el final del mismo se sentaron definitivamente las bases de una sólida jurisprudencia en torno a la idea de desechar los recursos intentados. De aquí en adelante, pese a los cambios legislativos que se van a materializar, la jurisprudencia se mantendrá fiel al estilo diseñado: declarar inadmisible el recurso de casación en este ámbito.

1.4. Cuarta Época: (1972-1983). Este período se extiende desde la publicación de la ley 17.642, que introdujo importantes adiciones a la ley 7.821, y el año 1983 en que se dictó la ley 18.216, que derogó la anterior normativa. Esta etapa se caracteriza por la pérdida de los buenos argumentos que habían caracterizado la época anterior (sobre todo en su inicio). Ya no se visualiza el predominio del recurso de casación en la forma sobre el de fondo. El legislador, a través de la ley 17.642, interviene y modifica la ley 7.821 para corregir algunos errores que se habían detectado en su aplicación práctica: los jueces, ahora, están facultados para conceder de oficio la suspensión de la pena, y, muy importante, deben fundar debidamente tanto el rechazo como la concesión de dicha suspensión.

Comienza también en esta época a imponerse la idea en nuestros tribunales que esta suspensión no forma parte de la sentencia definitiva, aunque materialmente la integre, ni constituye una sentencia interlocutoria que ponga término al juicio o haga imposible su continuación. Este último argumento en su formulación es nuevo. Es la época en que la Corte Suprema comienza a hacer uso de sus facultades de oficio. En más de una oportunidad desecha el recurso intentado, pero de oficio anula la sentencia y concede la medida.

En el informe de la Comisión de Constitución, Legislación y Justicia de la H. Cámara de Diputados, se señaló sobre el proyecto que modificaba la ley 7.821:

[Q]ue después de 25 años de aplicación de esta norma se ha podido ver que es necesario introducir algunas modificaciones que permitan una mejor aplicación de ella. [...] Ahora bien, como se señala en la letra a) antes transcrita, la facultad del juez para remitir condicionalmente la pena se limita a que la sentencia haya aplicado una pena restrictiva o privativa de libertad que no exceda de un año. Se estima por parte del diputado autor de la moción, criterio que también compartió la Comisión, que el hecho de haberse aprobado una norma legal tan restringida, se justificaba en la oportunidad de su dictación al no conocerse, en la aplicación permanente de la citada disposición, las consecuencias que podrían nacer de ella, pero

${ }^{24}$ RDJ, t. LXVI (1969), 2 a parte, sección cuarta, pág. 138. 
ahora, después de un período de 25 años, se ha hecho unánime el criterio de ampliar esta facultad con el objeto de permitir que puedan acogerse a ellas un mayor número de condenados, con el propósito de buscar su regeneración e incorporación a la sociedad ${ }^{25}$.

Entre las mejoras que se introdujeron a la referida ley quizá si la más importante - en el plano sustantivo - fue el aumento del plazo de uno a tres años de la pena privativa o restrictiva de libertad susceptible de suspensión. En el aspecto procesal, en primer término, se zanjó la discusión que se había suscitado en torno a si los jueces podían conceder este beneficio motu propio. Al respecto, en el informe de la comisión que estamos analizando se observó lo siguiente:

Asimismo, se produjo un cambio de opiniones acerca de si este beneficio debía ser solicitado por la parte o ser aplicado de oficio por el juez. Se concluyó que las disposiciones legales pertinentes son claras y precisas sobre la materia, no existiendo duda al respecto, pero con el objeto de reforzar este criterio unánime de la Comisión, se estimó conveniente introducir una modificación en el inciso primero del artículo $1^{\circ}$ de la ley $\mathrm{N}^{\mathrm{o}} 7.821$, en el sentido de agregar un frase a continuación de la palabra "suspender", del tenor siguiente: "de oficio o a petición de parte"26.

Un segundo aspecto procesal que se abordó fue el relativo a la necesaria fundamentación de la resolución que desechaba la suspensión de la pena. Como se recordará, este fue uno de los aspectos que criticamos de la ley 7.821 al analizar la forma cómo el legislador previó el control de esta institución por los superiores jerárquicos, porque dicha fundamentación se exigió sólo para el evento de concederse la medida, mas no para su rechazo. En esta oportunidad se corrigió dicha omisión:

A indicación del señor Ministro de Justicia, se agregaron dos nuevos incisos al artículo $2^{\circ}$ de la Ley $\mathrm{N}^{\circ}$ 7.821. Conforme al primero de ellos, si el Tribunal respectivo estima improcedente hacer uso de su facultad para remitir la pena, deberá expresarlo así, fundadamente, en la sentencia ${ }^{27}$.

Sobre este punto, en la discusión del proyecto en el Senado de la República se observó que: «También establece el proyecto la obligación de que el tribunal señale las razones por las cuales estima que el procesado no es merecedor de la remisión condicional de la pena. Es decir, el tribunal podrá pronunciarse de

\footnotetext{
${ }^{25}$ Cámara de Diputados, sesión 36a . del martes 4 de enero de 1972, págs. 2612 y 2613.

26 Ídem, pág. 2613. En la discusión del proyecto, precisamente se señaló en el Senado que «por tal razón, la iniciativa resuelve un gran problema que se estaba produciendo. En lo sucesivo no sólo se concederá la remisión condicional de la pena cuando el reo o el abogado lo solicite, sino que el tribunal podrá otorgarla de oficio, cuando concurran los requisitos señalados». Diario de Sesiones del Senado, sesión $66^{a} .10$ de marzo de 1972, pág. 3706

${ }^{27}$ Diario de Sesiones del Senado, sesión 60ª (anexo documentos), 23 de febrero de 1972, pág. 3.339.
} 
oficio para otorgar dicho beneficio, y deberá fundar su fallo cuando estime que la persona no merece que se le otorgue la remisión condicionalı ${ }^{28}$.

Finalmente, se implementó a la luz de esta reforma la posibilidad de apelar sólo de la negativa de concesión de la suspensión:

[...]. El segundo de dichos incisos establece una regla excepcional, para permitir que el condenado a quien se niegue el beneficio de la remisión condicional en la sentencia de primera instancia, y siempre que la sentencia no sea apelada en lo demás por éste o deba ser elevada en consulta ante el Tribunal superior, pueda apelar única y exclusivamente de la denegatoria del beneficio ${ }^{29}$.

Como puede vislumbrarse, los cambios procesales introducidos a ley 7.821 no fueron menores. La necesidad de fundar el rechazo del beneficio de la remisión condicional de la pena, buscaba corregir la práctica judicial que se había asentado, en cuanto los jueces no se sentían obligados a explicitar las razones de su negativa, lo que, como hemos visto, adicionalmente fue utilizado para desechar el recurso de casación. Lamentablemente estos cambios no significaron una alteración sustancial del camino que ya venían transitando nuestros tribunales. Veamos qué sucedió en el aspecto judicial.

El año 1973 la Corte es categórica en afirmar que «como la resolución que se pronunció sobre la remisión condicional de la pena no constituye una sentencia definitiva, ni interlocutoria que ponga término al juicio o haga imposible su continuación, no puede prestarse acogida a este vicio de nulidad $\iota^{30}$. Este argumento de la Corte es exquisitamente formal, porque el vicio que se había denunciado era precisamente la circunstancia de que la sentencia carecía de los fundamentos por los cuales no se había concedido el beneficio de la remisión condicional de la pena, obligación que, como acabamos de ver, había adicionado la ley 17.642 al artículo 2 de la ley 7.821. Pero nuestro máximo tribunal se

\footnotetext{
${ }^{28}$ Diario de Sesiones del Senado, sesión 66 a 10 de marzo de 1972, pág. 3.707.

${ }^{29}$ Diario de Sesiones del Senado, sesión 60 (anexo documentos), 23 de febrero de 1972, pág. 3.339. En la discusión en el Senado de la República esta modificación fue, en general, bien recibida: Señaló al respecto el senador Luengo: A mi juicio, tal medida es muy conveniente, porque puede ocurrir que el reo acepte la pena, pero considere que es merecedor del beneficio de la remisión condicional. Entonces el proyecto establece la posibilidad de que apele sólo del fallo del tribunal que no dio lugar a dicho beneficio; de modo que la parte concerniente al fallo que lo condenó no será revisada por el tribunal superior, al contrario de lo que ocurre con el procedimiento penal actual, pues hoy día, una vez deducida la apelación del fallo, el tribunal superior puede, inclusive, aumentar la pena, aun cuando el reo sostenga en su apelación que la pena fue excesiva. En este caso, cuando se reclame únicamente de la denegación de la remisión condicional de la pena, el tribunal de alzada deberá revisar sólo ese aspecto del fallo. No podrá conocer nuevamente la parte por la cual se aplicó un pena restrictiva o privativa de libertad». Diario de Sesiones del Senado, sesión $66^{\mathrm{a}}$, 10 de marzo de 1972, pág. 3.707.

${ }^{30} \mathrm{RDJ}$, t. LXX (1973), 2 2 . parte, sección cuarta, pág. 60.
} 
REJ - Revista de Estudios de la Justicia - No 10 - Año 2008

comporta como si dicha enmienda no se hubiere materializado. $\mathrm{O}$ tal vez, porque era consciente de dicho cambio, modifica su discurso: ya no se dice que no procede anular la sentencia porque los tribunales no están obligados a fundamentar el rechazo de este beneficio, sino que no procede anular el fallo porque la naturaleza de la resolución recurrida no hace procedente la casación ${ }^{31}$.

Se llega en esta fase a una construcción del tipo silogístico, bien representada por la siguiente resolución de nuestra Corte Suprema:

Que en el caso en estudio el fallo de alzada confirmó el del juzgado no alterando ni sus considerandos, ni su resolución, pero denegó la remisión condicional concedida en la primera instancia;

Que la remisión condicional de la pena, es un atributo que la ley otorga al tribunal, al facultarlo para beneficiar a determinado reo, a quienes se le condena a penas restrictivas o privativas de libertad;

Que esta remisión es independiente del proceso penal el que tiene por objeto el descubrimiento del reo y su caución, proceso que concluye en la sentencia que determina la pena y las indemnizaciones que debe pagar el sancionado;

Que la declaración del tribunal sobre remisión de la pena no forma parte de lo resolutivo de la sentencia. La propia ley que crea esta franquicia se refiere a la "suspensión de la ejecución que imponga la sentencia condenatoria". Esta redacción demuestra que el beneficio se da después de condenado el reo, siendo esta resolución sucesiva a la de la condena;

Que en virtud de lo dicho, la sentencia impugnada, al confirmar la de primera instancia sin introducir alteración alguna en el proceso, no necesitó dar cumplimiento a todos los presupuestos formales a que se refiere el artículo 500 del CPP y, por lo tanto, no procede acoger el recurso de casación en la forma fundada en esta omisión ${ }^{32}$.

Como se puede apreciar, hay una completa escisión entre la sentencia condenatoria y la remisión condicional de la pena. Lo que con una impecable argumentación había unido la Corte Suprema en 1959 «[...] todo lo pertinente al beneficio se incorpora, íntegramente a la sentencia, y forma con ella un solo todo

\footnotetext{
${ }^{31}$ En el mismo sentido véase RDJ, t. LXX (1973), 2ª parte, sección cuarta, págs. 96-101; Fallos del Mes $\mathrm{N}^{\circ} 188$ (julio de 1974), págs. 128-131; Fallos del Mes No 281 (abril de 1982), págs. 87 y 88; RDJ, t. LXXX (1983), 2ª parte, sección cuarta, págs. 6 y 7.

32 RDJ, t. LXXI (1974), 2a . parte, sección cuarta, pág. 255. En el mismo sentido resolviendo recursos de casación en el fondo véase Fallos del Mes, No 196 (abril de 1975), págs. 26-28; RDJ, t. LXXV (1978), 2a . parte, sección cuarta, págs. 336-338; RDJ, t. LXXX (1983), 2ª parte, sección cuarta, págs. 91 y 92.
} 
consubstancial. No se introduce, por este suceso, una cuestión accesoria o independiente, toda vez que el reo adquiere una situación de trascendencia, ligada a la condena, dado que la pena privativa de libertad queda expuesta a mantenerse en suspenso y hasta puede desaparecer con arreglo a lo dispuesto en el artículo $3^{\circ}$ de la mencionada ley», se olvida por completo en estos años.

Aludíamos al comenzar esta etapa que ella también mostró la tendencia de la Corte Suprema de hacer uso de sus facultades de oficio. En más de una oportunidad desecha el recurso intentado, pero de oficio anula la sentencia y concede la medida. Así, por ejemplo, se resolvió: «Que al negar lugar a la remisión de la pena solicitada por el reo, la sentencia le ha inferido un agravio que este tribunal debe enmendar de oficio en uso de sus facultades disciplinarias ${ }^{33}$. Esta será una tendencia que se mantendrá en el siguiente período ${ }^{34}$.

1.5. QUINTA Y ÚlTiMA ÉPOCA: (1983-2000). Este período comprende desde la publicación de la ley 18.216, el 14 de mayo de 1983, y la entrada en vigor del Código Procesal Penal que, como se sabe, puso término al recurso de casación en la legislación criminal chilena.

El propósito de la ley 18.216, expresado en el mensaje del Ejecutivo, fue introducir al sistema de ejecución de las penas privativas y restrictivas de libertad «dos nuevas formas de alternativas a las que se ha denominado, respectivamente, Reclusión Nocturna y de Libertad Vigilada o Probación. A fin de diferenciar convenientemente las dos nuevas instituciones alternativas que se incorporan a la única hasta hoy existente — remisión condicional de la pena- se han modificado algunas disposiciones de la ley $7.821 »^{35}$. Se agregó en el aludido mensaje que con el objeto de que «exista la debida concordia y armonía, se ha estimado del caso elaborar un nuevo texto refundido de esa ley en que, de manera sistemática, se establezcan las normas referentes a cada una de las instituciones y las que son comunes a algunos o a todos ellos» ${ }^{36}$.

En materia procesal se mantuvieron casi sin alteración las disposiciones consagradas en la legislación precedente, agrupadas ahora en el título III de la ley, relativo a las normas generales aplicables a las tres medidas previstas. Los tribunales mantuvieron la competencia para decretar de oficio estas medidas, y el condenado la facultad de apelar exclusivamente de la decisión denegatoria o revocatoria del beneficio. Por su parte, en el artículo 24 se reiteró la obligación de

\footnotetext{
${ }^{33}$ Corte Suprema, primera sala, 2 de octubre de 1970 en Fallos del Mes No 143, págs. 255 y 256. En el mismo sentido véase Fallos del Mes No 276 (noviembre de 1981), págs. 524-530, especialmente págs. 529 y 539. También en RDJ, t. LXXVIII (1981), 2a . parte, sección cuarta, págs. 230-235.

34 Véase, a propósito de un recurso de queja rechazado y de oficio acogido, Gaceta Jurídica $\mathrm{N}^{\circ} 88$ (1987), págs. 56-58. En materia de casación de oficio vid. Gaceta Jurídica No 126 (1990), págs. 75 y 76.

35 Mensaje del Ejecutivo, Boletín No 239-07, 25 de mayo de 1982, pág. 25.

${ }^{36}$ Ídem.
} 
REJ - Revista de Estudios de la Justicia - No 10 - Año 2008

los jueces de fundar el rechazo o aceptación de alguno de los beneficios previstos en la ley, con un importante añadido: en caso de acogerse dicho beneficio se elevó su fundamentación al grado de convicción. Es decir, nada menos que se equiparó con el grado necesario para condenar a un sujeto, de acuerdo a lo previsto en el art. 456 (posteriormente 456 bis) del CPP-1906. Todo lo anterior, lógicamente, en la respectiva sentencia condenatoria. De este modo, dispuso el aludido artículo 24:

«El tribunal que conceda, de oficio o a petición de parte, alguno de los beneficios previstos en los Títulos anteriores, deberá así ordenarlo en la respectiva sentencia condenatoria, expresando los fundamentos en que se apoya y los antecedentes que han dado base a su convicción.

Si el tribunal negare la petición para conceder alguno de los beneficios previstos en esta ley, deberá exponer los fundamentos de su decisión en la sentencia».

De allí que en la discusión de esta ley, se hubiere señalado por la Segunda Comisión Legislativa que «el artículo 24 se refiere a la forma como el tribunal, de primera o segunda instancia, debe conceder el beneficio que sea procedente. Se modificó el texto originalmente propuesto con el fin de precisar la forma como el tribunal puede conceder los beneficios y en especial la fundamentación que de ello debe hacer en la sentencia al otorgarlo cuando deniegue su concesión al serle solicitado específicamente» ${ }^{37}$.

Ahora bien, lo extraordinario de este período es que, pese a que se contaba con un nuevo, mejor y mucho más extenso texto normativo - la ley 18.216 tenía originalmente 31 artículos permanentes y dos transitorios $-{ }^{38}$, no se acogió un solo recurso de casación que permitiera invalidar la sentencia de segunda instancia que había revocado o no había concedido alguno de los beneficios regulados en la ley $18.216^{39}$. A estas alturas ya estaba sólidamente impregnada en nuestra jurisprudencia la idea de que los referidos beneficios no formaban parte de la sentencia definitiva, ni constituían una sentencia interlocutoria que pusiera término al juicio o hiciera imposible su continuación. Veamos algunos fallos emblemáticos al respecto:

El año 1985, resolviendo un recurso de casación en la forma, nuestra Corte Suprema señaló:

\footnotetext{
${ }^{37}$ Informe complementario de la Segunda Comisión Legislativa, Boletín No 239-07, pág. 243.

${ }^{38}$ No se olvide que el artículo 31 de esta ley dispuso que: «Deróganse la ley 7.821, sobre remisión condicional de la pena; la ley 17.642 y el decreto ley $\mathrm{N}^{\circ} 1968$, de 1977 ».

${ }^{39}$ Hay algunos recursos que se acogieron (normalmente por errónea valoración de las atenuantes alegadas por la defensa del condenado) que al rebajar la pena impuesta por los jueces de fondo, por vía secuencial concedieron alguno de los beneficios previstos en la legislación. Véase al respecto: Fallos del Mes No 416 (julio de 1993), págs. 470-473; Fallos del Mes No 416 (julio de 1993), págs.478-482.
} 
Que el recurso de casación en la forma expresa que la sentencia no ha sido extendida en la forma dispuesta por la ley, por cuanto se omitió en ella señalar que el reo debía cumplir las condiciones que establece el artículo $5^{\circ}$ de la ley 18.216 para tener derecho al beneficio de la remisión condicional de la pena privativa de libertad impuesta en el fallo impugnado;

Que si bien la declaración que ordena le ley antes referida debe hacerse en la sentencia definitiva, tal resolución no tiene el carácter que la ley le otorga a esta resolución, en el proceso penal de acuerdo con lo dispuesto en el artículo 500 del Código de Procedimiento Penal, ni constituye tampoco sentencia interlocutoria de aquellas contra las cuales procede el recurso, porque no pone término al juicio ni hace imposible su continuación ${ }^{40}$.

Como se aprecia la sentencia parece un calco de otras que hemos analizado en este trabajo. No deja de ser llamativa la insistencia de nuestros tribunales de señalar que la parte de la sentencia condenatoria que se pronuncia sobre alguno de los beneficios previstos en la ley 18.216, si bien materialmente se contiene en ella no participa de dicho carácter. Esta argumentación produce cierta perplejidad porque razonablemente cabe preguntarse si no participa de dicho carácter ¿qué naturaleza tiene? Volveré más adelante sobre esta pregunta.

El año siguiente — 1986-la Corte Suprema, conociendo de un recurso de casación en el fondo, resolvió:

Que el recurso de casación sólo se concede en contra de las sentencias definitivas y las interlocutorias, cuando ponen término al juicio o hacen imposible su continuación; Que el recurso de casación en el fondo interpuesto por el reo [...] ataca la sentencia de segunda instancia solamente en la parte que confirma la de primer grado que no da lugar a la reclusión nocturna solicitada por el procesado; [...] Que, además de las disposiciones de la citada Ley 18.216 relativas a la forma de resolver los beneficios que contempla denotan con claridad que esta decisión es distinta de las que son propias de la sentencia definitiva donde debe insertarse, aunque lógicamente está subordinada a que en ésta se imponga una pena; Que, por otra parte, si bien es cierto la sentencia en estudio puede calificarse de sentencia interlocutoria, ella por sí sola no pone término al juicio ni hace imposible su prosecución; Que en consecuencia,

40 RDJ, t. LXXXII (1985), 2ª parte, sección cuarta, pág. 3. En el mismo sentido véase: RDJ, t. LXXXI (1984), 2a . parte, sección cuarta, pág. 209; Fallos del Mes No 335 (octubre de 1986), págs. 740 y 741; Fallos del Mes No 348 (noviembre de 1987), págs. Fallos del Mes No 374 (enero de 1990), págs. 917 y 918; Fallos del Mes No 395 (octubre de 1991), págs. 552 y 553. 
debe concluirse que la decisión relativa al beneficio de la reclusión nocturna no es susceptible de ser impugnada por el recurso de casación ${ }^{41}$.

Al menos en esta resolución, sin dar razones eso sí, se le da algún calificativo a esta parte del fallo condenatorio: él sería una sentencia interlocutoria, aunque claro no de aquéllas que hacen procedente el recurso de casación.

Finalmente, el año 1997 la Corte Suprema resuelve que «el sentenciado ha deducido recurso de casación en el fondo por la causal 1 12. del artículo 546 del Código de Procedimiento Penal, señalando que se ha incurrido en error que la configura, al omitirse pronunciamiento acerca de los beneficios que contempla la ley 18.216, pese a que la rebaja de la pena acordada en segunda instancia permitía, en su concepto, una declaración favorable en tal sentido; Que si bien la referida ley prescribe que el tribunal decidirá en la sentencia condenatoria si concede o no alguno de los beneficios o medidas alternativas de que se ocupa, la expresada resolución no es parte constitutiva de la sentencia definida [sic] del juicio penal, por cuya razón la causal esgrimida no le es apreciable, constituyendo, en cambio, un pronunciamiento administrativo razona [sic] que se incorpora al fallo por disposición de la ley; Que, en estas condiciones, dicha declaración no es atacable por la vía del presente recurso, por no tener el carácter de sentencia definitiva inapelable o interlocutoria inapelable que ponga fin al juicio o haga imposible su continuación» ${ }^{42}$.

En definitiva, la jurisprudencia de nuestra Corte Suprema pese a los cambios que en esta materia había introducido el legislador, sostendrá invariablemente hasta el año 2000 (fecha en que desaparece el recurso de casación en el orden procesal penal chileno) la inadmisibilidad del recurso de casación para revisar las sentencias de segunda instancia, que se pronunciaban sobre las medidas alternativas reguladas en la ley $18.216^{43}$. Lo más sorprendente de esta interpretación es que ella será retomada, sin mayor cuestionamiento, a propósito del recurso de nulidad previsto en el actual Código Procesal Penal. (Sobre este punto volveré en el último capítulo de este informe).

Al comenzar este estudio, expuse que la situación paradojal a la que nos enfrentamos encontraba sus causas en dos razones diversas. He explicado la primera de ellas. Es el momento de avanzar sobre la segunda (puntos III y IV).

\footnotetext{
41 Fallos del Mes, № 330 (1986), págs. 261 y 262.

42 Fallos del Mes No 462 (1997), págs. 700 y 701.

43 Véase al respecto: Fallos del Mes No 382 (septiembre de 1990), págs. 538 y 539; Fallos del Mes No 418 (septiembre de 1993), págs. 758-760; Fallos del Mes No 433 (diciembre de 1994), págs. 994 y 995; Fallos del Mes No 449 (abril de 1996), págs. 758-760; Fallos del Mes No 449 (abril de 1996), págs. 796 y 797; Fallos del Mes No 462 (mayo de 1997), págs. 753-755; Fallos del Mes No 475 (junio de 1998), págs. 852-860.
} 


\section{Evolución del recurso de apelación en relación con la aplicación de la ley 18.216.}

2.1. Sentencia de primera instancia. Antes del año 2000 el escenario en el foro nacional, en términos generales, era el siguiente: la sentencia condenatoria de primera instancia debía resolver la petición de la defensa — normalmente realizada en un otrosí de la contestación de la acusación- de otorgar alguna de las medidas reglamentadas en la ley 18.216. Esta sentencia, fuere que accediere o no a la petición, podía impugnarse a través del recurso de apelación.

Incluso, no se olvide, que la ley 18.216, siguiendo lo dispuesto en la ley 7.821 después de 1972, sancionó en el artículo 25 —original— lo siguiente: «Sin perjuicio de las reglas generales sobre apelación y consulta, el reo también podrá apelar, de la decisión denegatoria o revocatoria de los beneficios que establece esta ley, caso en el cual el Tribunal de Alzada sólo se pronunciará sobre la procedencia o improcedencia del beneficio».

Pues bien, en este punto es bueno tener presente que las Cortes de Apelaciones, en numerosas ocasiones, revocaron los fallos de primera instancia que no habían concedido alguna de las medidas alternativas a las penas privativas de libertad. En ocasiones, la Cortes esgrimían argumentos que técnicamente eran incorrectos pero útiles para conceder el beneficio solicitado. Paradigmático, en este aspecto, resultaron los fallos de la Corte de Apelaciones Pedro Aguirre Cerda que calificó estos beneficios como medidas de carácter administrativo ${ }^{44}$. Así, el año 1984 señaló:

\footnotetext{
44 Esta situación, en verdad, se ha repetido a lo largo de la historia judicial chilena. Véase un interesante fallo de la Corte de Apelaciones de La Serena, de 26 de febrero de 1946. El proceso se siguió por infracción de la ley de elecciones y en él se condenó por el juez de Illapel al imputado a la pena de 61 días de reclusión, a la suspensión de cargo y oficio público durante el tiempo de la condena y al pago de las costas de la causa. Apelada dicha resolución fue confirmada por la Corte de Apelaciones de La Serena, con declaración que se suspendía la ejecución de la pena. En el fallo de segunda instancia se señaló lo siguiente: «Que en el caso en discusión, no está demás tener presente, que con la dictación de la ley 7.821 se quiso evitar la permanencia en prisión de los delincuentes primarios, condenados a penas pequeñas, porque tales sanciones difícil es que importen un medio práctico de regeneración o de enmienda y más de las veces, seguramente, será perjudicial para el individuo que ocasionalmente delinquió, que tiene dignidad y que se ve arrastrado a un encarcelamiento»; y «Que al disponer el tribunal sentenciador de $1^{\mathrm{a}}$. o de $2^{\mathrm{a}}$. instancia la remisión de la pena impuesta al reo, ejercita una facultad discrecional, por la que determina la manera cómo el reo debe cumplir lo fallado, para lo cual éste no necesita hacer petición de ninguna especie, porque son los jueces que deben compenetrarse del caso que fallan, de la persona del reo, de las circunstancias que lo rodean y resolver si es acreedor a tal medida». La resolución es significativa porque señala que estamos frente a una facultad discrecional que puede ejercerse oficiosamente, esto es, que no requiere petición de parte ya que se está determinando la forma cómo se debe cumplir el fallo. (Recuérdese que la facultad de proceder de oficio en esta materia sólo se reguló expresamente a partir de 1972). Como suele ocurrir en el ámbito judicial, los
} 
REJ - Revista de Estudios de la Justicia - No 10 - Año 2008

Que, reiteradamente, la Excma. Corte Suprema ha decidido que lo relacionado con la remisión condicional de la pena, si bien va inserta en una sentencia definitiva, no tiene dicho carácter, por cuyo motivo ha estimado que la decisión relativa a dicho beneficio no es susceptible de ser impugnada por el recurso de casación, el cual, como es sabido, se concede sólo contra las sentencias definitivas y las interlocutorias cuando ponen término al juicio o hacen imposible su continuación.

Que en orden a resolver el problema planteado se hace indispensable calificar previamente la naturaleza jurídica de la decisión que concede el ya nombrado beneficio. Si bien el artículo 25 de la ley 18.216 autoriza al reo para apelar de la decisión denegatoria o revocatoria del beneficio y de ello podría derivarse que se trata de una sentencia definitiva o interlocutoria que, por consiguiente, una vez ejecutoriada produce el efecto de cosa juzgada que impide su posterior modificación, es menester tener presente, además de la jurisprudencia de nuestro más alto tribunal referida en el motivo anterior que la propia ley en sus artículos 6 y 26 hace revocable este beneficio, cuando concurren las circunstancias que en ellos se señalan. Si se tratara de una sentencia definitiva o interlocutoria, ello no podría acontecer, por los efectos de inmutabilidad que ellas producen una vez que quedan firmes.

Esta reflexión lleva a concluir que esta materia dice relación más bien con un aspecto o medida indudablemente administrativa, que incide en el cumplimiento de la pena privativa o restrictiva de libertad que impone la sentencia, cuya aplicación queda suspendida, y por consiguiente, susceptible de ser modificado en el punto que plantea el reo en lo principal de fojas 254. [...] Este razonamiento permite inferir que no existe a este respecto el desasimiento invocado por el juez de primera instancia en la resolución recurrida, que sea un obstáculo para resolver favorablemente la citada petición del reo ${ }^{45}$.

Esta argumentación es muy curiosa. Si se reflexiona bien, lo que preocupa a la Corte de San Miguel es lo siguiente: de aceptarse que la resolución que rechaza la aplicación de alguna de las medidas previstas en la ley 18.216 es una sentencia definitiva o interlocutoria, no podría el tribunal conceder dichos beneficios una vez que la aludida resolución estuviese firme (por el efecto de cosa juzgada que tienen las sentencias definitivas o interlocutorias según lo previene el artículo 175 del CPC en relación con el 182 del mismo Código). Para obviar este

jueces al buscar la justicia del caso concreto recurren a interpretaciones que, posteriormente, pueden resultar peligrosas. Aquí se da el calificativo de facultad discrecional porque se desea actuar de oficio, ipara conceder la suspensión! Gaceta de los Tribunales, 1945, 1er. semestre N²8, págs. 206210.

${ }^{45}$ Gaceta Jurídica, No 47 (1984), pág. 90. 
problema, argumenta que en verdad esta resolución no es una resolución jurisdiccional, sino que es una medida «indudablemente administrativa». Con lo cual, si bien soluciona el problema de la cosa juzgada, porque se supone que las medidas administrativas no van acompañadas del efecto de inmutabilidad que caracteriza a las resoluciones jurisdiccionales, abre un abanico de otros problemas.

No es este el momento de discutir cuál es la diferencia sustancial entre una actuación jurisdiccional y una administrativa, pero me parece a mí que calificar una resolución judicial que se pronuncia nada menos que sobre la manera cómo debe cumplirse la pena impuesta en la sentencia condenatoria, respecto de la cual hay que abrir en la actualidad todo un debate en sede judicial (véase artículo 343 inciso $4^{\circ}$ del $\mathrm{CPP}$ ) como una medida administrativa constituye un claro error jurídico, el cual le hace un flaco favor al sistema legal en su conjunto.

Si lo que deseaba la Corte era obviar el problema de la cosa juzgada - y sin entrar tampoco en la discusión sobre si las disposiciones relativas a la cosa juzgada del CPC pueden aplicarse sin más en el proceso penal-, pudo perfectamente señalar que la tantas veces aludida resolución era un simple auto, esto es, una resolución que resuelve un incidente y que no establece derechos permanentes para las partes. Resolución judicial que como se sabe, no va aparejada del efecto de cosa juzgada (artículo 181 del CPC). O resolver lo más lógico, que la resolución judicial que resuelve sobre los beneficios de la ley 18.216 tiene un régimen propio de estabilidad y recursos (artículos 6, 25, 26, 27 de dicha ley y 18 del Código Penal) que siempre está sujeto a la cláusula rebus sic stantibus, por la cual los tribunales siempre pueden modificarla si cambian las circunstancias que tuvieron en vista al momento de resolver la petición ${ }^{46}$. Tal cual ocurre, por ejemplo, con las resoluciones que resuelven sobre una petición de alimentos, privilegio de pobreza o de medidas precautorias, que, hasta dónde conozco, a nadie se le ha ocurrido — todavía- calificar como simples medidas administrativas.

Lógicamente, estas declaraciones de la Corte no son inocuas. La misma Corte de San Miguel reiteró su doctrina a lo menos en dos oportunidades más y la Corte Suprema la hizo suya en otras $\operatorname{dos}^{47}$. El 9 de diciembre de 1985 el tribunal de alzada argumentó que «de las normas relacionadas se concluye que la cuestión en referencia es de carácter administrativo por referirse a medidas sobre ejecución de las penas privativas o restrictivas de libertad y, por tanto, no existe inconveniente legal en acceder a lo pedido por el reo si existe el impedimento justificado aludido precedentemente [alude al inconveniente de cumplir con el pago de las indemnizaciones civiles a las que fue supeditada la remisión de la

\footnotetext{
46 Véase, por ejemplo, Gaceta Jurídica No 50 (1984), pág. 115. Fallos del Mes No 332, pág. 447. En contra de esta interpretación puede verse Gaceta Jurídica No 95 (1988), págs. 70-72. Fallos del Mes $\mathrm{N}^{\circ}$ 346, pág. 651.

47 Véase, Gaceta Jurídica No 118 (1990), págs. 48 y 49; y Fallos del Mes № 462 (1997), págs. 700 y 701.
} 
pena]» ${ }^{48}$. Finalmente, el 25 de junio de 1991, en un fallo que valdría la pena analizar más en detalle y que por motivos de espacio no podemos hacer en este momento, resolvió:

Que abona este predicamento, la circunstancia, de que, en forma expresa, la ley 19.047, se refiere a quienes se encuentran actualmente cumpliendo condenas privativas o restrictivas de libertad por alguno(s) de los delitos especiales mencionados en dicha ley, sin que constituya obstáculo para obtener la medida alternativa, el que hubiere sido denegada en la sentencia condenatoria, lo que en opinión de los sentenciadores refuerza el predicamento de que esta decisión es más bien de carácter administrativo y no le afecta la cosa juzgada de la sentencia. Sin perjuicio de las motivaciones calificadas que llevaron al legislador a dictar estas reglas especiales, el imperativo de justicia requiere que la suspensión de la pena de encierro, cuyos males son ampliamente conocidos, esté al alcance de todos los condenados, incluso rematados, cualquiera que sea el delito cometido, en la media [sic] que se satisfagan los requisitos legales» ${ }^{49}$.

Toda la argumentación de la Corte de Apelaciones se sustenta en la necesidad de «hacer justicia», lo cual en opinión del Tribunal «requiere que la suspensión de la pena de encierro, cuyos males son ampliamente conocidos, esté al alcance de todos los condenados, incluso rematados». La misma finalidad, como hemos destacado, pudo conseguirse con un argumento más razonable, sin necesidad de abandonar el ámbito jurisdiccional.

2.2. Entrada en vigor del Código Procesal Penal $(2000)^{50}$ : el ocaso del recurso de apelación. Como es bien conocido, el nuevo sistema procesal penal significó un giro copernical en la forma cómo se impartía la justicia criminal en Chile. En lo que a nosotros importa, una de las grandes transformaciones que se llevaron adelante fue a propósito de los medios de impugnación. En el mensaje del Ejecutivo se dio cuenta de esta situación: «La concepción básica que inspira el régimen de recursos que el proyecto propone implica un radical cambio en el sistema de controles de la actividad de los jueces penales. [...]. Los cambios más importantes que el proyecto propone se refieren a la apelación y a la consulta. Estos mecanismos de control no resultan en general compatibles con el nuevo sistema».

De esta manera, el artículo 364 del Código Procesal Penal dispuso lo siguiente: «Serán inapelables las resoluciones dictadas por un tribunal de juicio oral en lo penal». De este modo la sentencia condenatoria dictada por el tribunal del

\footnotetext{
48 Gaceta Jurídica $\mathrm{N}^{\circ} 66$ (1985), pág. 89.

49 Gaceta Jurídica No 132 (1991), pág. 96.

50 Pese a que la entrada en vigor del Código Procesal Penal, como se sabe, fue por etapas (artículo 484 del mismo), en este trabajo para evitar complicaciones tomaremos como fecha de vigencia el año 2000.
} 
juicio oral en lo penal, donde se contiene la decisión en torno a las medidas alternativas de la ley 18.216, no es susceptible de impugnar a través del recurso de apelación ${ }^{51}$.

Por otro lado, la ley 19.806, de 31 de mayo de 2002, sobre normas adecuatorias del sistema procesal penal chileno, modificó varias disposiciones de la ley 18.216, entre ellas, el artículo 25 de la ley 18.216, antes trascrito.

La nueva legislación tuvo como propósito, como es sabido, adecuar a la regulación del nuevo sistema de enjuiciamiento criminal el resto de las normas del ordenamiento jurídico nacional. En lo que a nosotros interesa, el proyecto del Ejecutivo originalmente derogaba el artículo 25 (artículo $16 \mathrm{~N}^{\circ} 5$ del proyecto). Fue durante la discusión parlamentaria donde se optó por su modificación. De este modo, el artículo 25 quedó finalmente redactado de la siguiente manera: «La decisión revocatoria de los beneficios que establece esta ley será apelable ante el tribunal de alzada respectivo» ${ }^{52}$.

Fruto de esta ley adecuatoria, se suprimió la alternativa que tenía el condenado de apelar sólo de la negativa del tribunal de primera instancia de otorgarle alguna de las medidas alternativas a las penas privativas de libertad, y sólo se dejó para los eventos en que el tribunal de primera instancia, por ejemplo, por incumplimiento del condenado de alguna de las obligaciones impuestas, revocare el beneficio concedido. De este modo, como se comprenderá, prácticamente desapareció el recurso de apelación como mecanismo normal de impugnación en esta materia ${ }^{53}$.

${ }^{51}$ La única posibilidad que hoy día se encuentra vigente de apelar de estos beneficios se encuentra a propósito del procedimiento abreviado. Véase artículos 412, 413 y 414 del Código Procesal Penal.

52 El informe de la Comisión de Constitución, Legislación, Justicia y Reglamento del Senado expresó que se deroga el artículo 25 que «faculta al reo para apelar de la decisión denegatoria o revocatoria de los beneficios que establece esta ley, caso en el cual el Tribunal de Alzada sólo se pronunciará sobre la procedencia o improcedencia del beneficio». Sin embargo, la Comisión advirtió que, si se aprobase la derogación, no podría apelarse de la resolución que deniegue un beneficio ni de la que lo revoque. Les pareció que podría justificarse en el caso de la negativa, pero, tratándose de la revocación de un beneficio ya concedido y del cual puede haberse encontrado gozando largo tiempo una persona, es razonable permitir que tal medida pueda ser revisada por el tribunal superior. Prefirió, por tanto, sustituir el artículo, para consignar que la decisión revocatoria de los beneficios que establece esta ley será apelable ante el Tribunal de Alzada respectivo. Diario de Sesiones del Senado, 16 de octubre de 2001, Sesión $8^{a}$ Ordinaria (anexo documentos), pág. 597.

$53 \mathrm{Al}$ respecto la Corte de Apelaciones de Santiago, el 30 de marzo de 2006, en causa rol 342-2006, señaló: «Que la sentencia dictada por el Juez del $4^{\circ}$ Juzgado de Garantía de Santiago, ha dispuesto en su considerando sexto, que respecto a la requerida [...] no se le considerara ningún de los beneficios que contempla la ley 18.216, por cuanto del tenor de su extracto de filiación y antecedentes del que se hiciera lectura por el fiscal en la audiencia, consta haber sido condenada por otros delitos de la misma especie [...] como autora de hurto a la pena de un año de presidio menor con el beneficio de reclusión nocturna. Decide este fallo en la parte resolutiva, conforme lo dispone el artículo 26 del Código de la Ley 18.216, revocar el beneficio de la reclusión nocturna 


\section{Evolución del recurso de queja en relación con la aplicación de las leyes 7.821 y 18.216 .}

3.1. Sentencia de segunda instancia. La sentencia de segunda instancia, en relación exclusivamente con el tema que ahora nos ocupa, podía impugnarse por medio de dos recursos que corrieron disímil suerte en la vida forense nacional. Por un lado, el recurso de casación (forma y fondo) cuya historia ya conocemos. Por el otro, el recurso de queja, que dominó sin contrapesos — en esta y otras materias - durante buena parte de la vida judicial chilena en la segunda mitad del siglo XX.

3.1.1. Situación del recurso de queja antes del año 1995. En este período, la Corte Suprema acogió y desechó recursos de queja interpuestos tanto por querellantes como por defensores. En su gran mayoría, en todo caso, el recurso de queja sirvió para conferir las medidas alternativas que habían sido denegadas por los jueces de segunda instancia. De estos fallos se desprende inequívocamente que la adjudicación de alguna de estas medidas era un derecho del condenado - y no una facultad graciosa de los jueces de fondo-, que sólo podía denegarse en la medida que no se cumplieran los requisitos legales exigidos para su concesión. Veamos, en orden meramente cronológico, alguna de estas resoluciones:

a) El 13 de enero de 1966 se acogió el recurso de queja deducido por el Fisco en contra de la Corte de Apelaciones, porque: «Del propio informe de los jueces recurridos aparece que los procesados (...) fueron condenados como responsables de delitos reiterados a una pena que excede de un año de privación de libertad, por lo que es improcedente la remisión condicional de dicha pena, declarada por aquellos jueces; y de acuerdo con lo dispuesto por el artículo 540 del COT, procede acoger el recurso de queja (...) y declarar que se deja sin efecto la remisión condicional de las penas concedida por la sentencia de esa Corte, a favor de los reos antes mencionados». (Fallos del Mes No 86, pág. 343) ${ }^{54}$.

que le fuera otorgado a la sentenciada [...], debiendo la referida Moreno cumplir la pena inicialmente impuesta en dicha causa [...]. Que al analizar las razones que han motivado este recurso de nulidad se puede concluir que la situación planteada por la recurrente, no se puede enmarcar en la situación que prevista en la letra g) del artículo 374 del Código Procesal Penal, por cuanto la Ley 18.216 sólo contempla en el artículo 25 deducir recurso de apelación contra la decisión denegatoria o revocatoria de los beneficios que establece esta ley». Lexis Nexis $\mathrm{N}^{\circ}$ de identificador 34.083.

${ }^{54}$ En sentido similar en cuanto acoge el recurso de queja y deja sin efecto el beneficio concedido por los jueces recurridos por no cumplirse con los requisitos legales, véase: Fallos del Mes $\mathrm{N}^{\circ} 299$, págs. 608-610; Fallos del Mes No 432, págs. 866-868. En cuanto la Corte Suprema acoge el recurso de queja y deja sin efecto el beneficio concedido mientras el condenado no pague la indemnización 
b) El 14 de junio de 1973 se acogió el recurso de queja deducido por el condenado a quien se le había negado la remisión condicional de la pena. Que lo cierto es, expresa nuestro máximo tribunal, «como lo representa el procesado al fundamentar el recurso de queja en examen, que los jueces recurridos no han podido sumar penas porque la Ley 7.821, que es de orden público, no lo permite al no establecerlo así expresamente (...); Que por concurrir en la especie, a favor del reo F., todos los requisitos exigidos por la Ley 7.821 (...) resulta evidente que los jueces recurridos incurrieron en falta que debe ser subsanada por la vía disciplinaria. De acuerdo con lo prevenido por el artículo 540 del COT se acoge el recurso de queja (...) y se declara que ha lugar a la remisión condicional de la pena de 541 días de presidio menor en su grado medio (...)». (Fallos del Mes No 175, págs. $104 \mathrm{y}$ 105. (La cursiva es mía).

c) El 7 de octubre de 1974 se acogió un recurso de queja deducido por la defensa del condenado: «Que al no dar lugar a la remisión condicional de la pena privativa de libertad impuesta al reo, en circunstancias que del proceso consta que éste reúne todos los requisitos que hacen procedente la concesión de tal beneficio, los jueces recurridos han cometido falta o abuso que debe ser enmendada por esta vía». Fallos del Mes $\mathrm{N}^{\circ} 189$, pág. 158 y también en Fallos del Mes No 191, pág. 224.

d) El 17 de marzo de 1977 nuestros ministros señalaron: «Que, atendido los antecedentes personales del reo, edad, conducta anterior y las modalidades y móviles del delito, es de presumir que (...) no volverá a delinquir, y encontrándose acreditado en los autos traídos a la vista las demás exigencias de la Ley 7.821, sobre remisión condicional de la pena, modificada por la Ley 17.642, resulta procedente otorgarle este beneficio. Que al no resolverlo así, los ministros recurridos han cometido falta que este Tribunal tiene facultad para corregir». Fallos del Mes No 220, pág. 39.

e) El 2 de agosto de 1977 se desechó el recurso de queja interpuesto por el querellante para dejar sin efecto el beneficio concedido por el tribunal de alzada. En su informe los jueces recurridos señalaron que el querellante y recurrente «ha deducido recurso porque estima que esta Corte en la sentencia aludida cometió falta o abuso, no obstante subir la pena impuesta al reo de 61 a 541 días, al mantener a favor de éste el beneficio de la remisión condicional de la pena (...). Ahora, en cuanto a la remisión condicional de la pena, el beneficio se concedió en cumplimiento de lo prescrito en la Ley 7.821, puesto que lo permite la extensión de la pena aplicada (...) el reo no ha sido condenado anteriormente por crimen o simple delito, y sus antecedentes personales, así como su conducta

civil a la que fue condenado, véase: Fallos del Mes No 338, págs. 1032 y 1033; Fallos del Mes No 341, págs. 143 y 144. 
REJ - Revista de Estudios de la Justicia - No 10 - Año 2008

anterior, naturaleza, modalidades y móviles determinantes del delito permiten presumir que no volverá a delinquir». El lacónico fallo de la Corte Suprema fue: «Con lo informado por los jueces recurridos y por no existir falta o abuso, se declara sin lugar el recurso de queja deducido en lo principal». (Fallos del Mes $\mathrm{N}^{\mathrm{o}} 225$, págs. 216 y 217$)^{55}$.

f) El 13 de noviembre de 1980 la Corte Suprema resolvió: «Que los antecedentes acumulados en el proceso $\mathrm{N}^{\circ} 15.193$ del rol del $2^{\circ}$ Juzgado del Crimen de Rancagua, que se ha traído a la vista, permiten estimar que el procesado y recurrente (...) cumple con los requisitos exigidos por la Ley 7.821, para ser acreedor al beneficio de la remisión condicional de la pena, de modo que los jueces recurridos al no decidirlo así han cometido falta que corresponde a este Tribunal enmendan». Fallos del Mes $\mathrm{N}^{\circ}$ 264, pág. $386 .^{56}$

g) El 12 de julio de 1982 la Corte Suprema desechó el recurso de queja interpuesto por el condenado en contra de la sentencia de segunda instancia que denegó el beneficio de la remisión condicional de la pena. Los ministros recurridos señalaron en su informe que: «Se recurre en nuestra contra por el único motivo de haber confirmado la sentencia de primera instancia en la parte en que por ésta no se remitió condicionalmente la pena impuesta al recurrente (...). De los antecedentes de esta causa aparece establecido con el extracto de filiación del inculpado y con su consecuencial certificación que éste fue condenado anteriormente (...) era imposible concederle por segunda vez el beneficio de la remisión condicional que reclama». (Fallos del Mes No 284, págs. 270 y 271).

h) El 10 de marzo de 1994, nuestro máximo tribunal resolvió que «habiéndose reducido en el fallo de segunda instancia la pena única de cinco años de presidio menor en su grado máximo que se le impusiera al procesado [...], como autor de los dos delitos de hurtos por los cuales fue

\footnotetext{
${ }^{55}$ Rechazando también el recurso de queja, pero con matices diversos, véase, Fallos del Mes $\mathrm{N}^{\circ} 260$, págs. 216 y 217.

${ }^{56}$ En sentido similar véase: Fallos del Mes No 278, págs. 620 y 621; Fallos del Mes No 280, págs. 43 y 44; Fallos del Mes $\mathrm{N}^{\circ} 289$, pág. 597 y 598. En esta misma línea de argumentación pero aplicando la ley $\mathrm{N}^{\circ} 18.216$ pueden verse: Fallos del Mes No 335, págs. 739 y 740; Fallos del Mes $\mathrm{N}^{\circ} 336$, págs. 829 y 830; Fallos del Mes No 343, págs.330 y 331; Fallos del Mes $\mathrm{N}^{\circ} 384$, págs. 701 y 702; Fallos del Mes $\mathrm{N}^{\circ}$ 391, págs. 235 y 236; Fallos del Mes No 394, págs. 479 y 480; Fallos del Mes No 394, págs. 488 y 489; Fallos del Mes $\mathrm{N}^{\circ}$ 395, págs. 570-572; Fallos del Mes $\mathrm{N}^{\circ}$ 413, págs. 168 y 169; Fallos del Mes $\mathrm{N}^{\circ}$ 415, págs. 377 y 378; Fallos del Mes No 431, págs. 740 y 741; Fallos del Mes No 433, págs. 987-993; Fallos del Mes $\mathrm{N}^{\circ} 437$, págs. 288-290. En cuanto acoge el recurso de queja y se obliga al tribunal de alzada a pedir el informe técnico para determinar si procede o no el beneficio de la libertad vigilada (artículos 15 letra c) de la ley 18.216 y 17 de su reglamento, véase: Fallos del Mes No 382, págs. 535 y 536 y Fallos del Mes No 421, pág. 1117. En cuanto la Corte Suprema concede el beneficio prescindiendo del informe, véase: Fallos del Mes No 450, págs. 1045-1048 (especialmente la última página).
} 
acusado [...], resultaba imperativo para los sentenciadores, en atención a lo señalado en el inciso segundo del artículo 24 de la ley 18.216, exponer los fundamentos para mantener la decisión de primera instancia de no otorgarle ninguno de los beneficios alternativos previstos en ese cuerpo legal, tomando en consideración que de los antecedentes que constan de las fotocopias autorizadas de los respectivos fallos agregados a este recurso, no aparecen elementos para excluirle de ellos. Que los jueces recurridos al no decidirlo así, han incurrido en falta que corresponde ser enmendada por esta vía disciplinaria». (Gaceta Jurídica No 165 (1994), pág. 87).

Como puede apreciarse de los fallos trascritos a título meramente indicativo y, principalmente, de los referidos en las respectivas notas al pie, la Corte en cada caso verificó si el condenado cumplía o no con los requisitos previstos por el legislador para la suspensión de la pena. Allí donde estimó que no los reunía (porque, por ejemplo, la pena excedía el máximo legal, o porque los antecedentes de la persona indicaban que había sido condenado con anterioridad o porque estimaba que constituía un peligro para la sociedad) negó la medida. En cambio, cuando concluyó que sí se reunían todos los antecedentes legales y que ello no había sido bien interpretado por los jueces de fondo, concedió la referida medida.

Ahora bien, después de analizar lo sucedido con el recurso de queja en esos años, surge una legítima interrogante: ¿Cómo es posible que los mismos jueces que en aquellos años desechaban el recurso de casación acogieran el de queja prácticamente por la misma causal? La respuesta parece estar - al menos en parte- en que el recurso de casación en materia penal sólo procedía en contra de determinadas resoluciones judiciales; en cambio el de queja procedía respecto de cualquier resolución judicial. Y fue esta circunstancia la que los llevó a acoger un recurso (el de queja) y a desechar el otro (el de casación). Para la casación sí fue determinante — como lo vimos_ la naturaleza de la resolución impugnada, no así para el recurso de queja.

3.1.2. Situación del recurso de queja después del año 1995. Como se sabe la Corte Suprema — desde la década de los setenta en adelante- se vio desbordada producto de la enorme cantidad de recursos de queja que los abogados diariamente interponían en defensa de sus clientes. Frente a esta realidad el legislador decidió intervenir. La ley 19.374, de 18 de febrero de 1995, modificó radicalmente el recurso de queja. También introdujo importantes cambios al recurso de casación. En el mensaje que acompañó al proyecto de ley se expresó lo siguiente:

Las disposiciones de este proyecto de ley tienen por objeto promover una profunda modernización en el Poder Judicial y, en especial, en su máximo tribunal, la Corte Suprema, tanto en su organización como en las materias y procedimientos que le incumben. (...). Por otra parte, se amplía el 
REJ - Revista de Estudios de la Justicia - No 10 - Año 2008

ámbito para interponer el Recurso de Casación y se restringe el del Recurso de Queja, con modificaciones a los artículos 767 y siguientes del Código de Procedimiento Civil, y a los artículos 545 y 549 del Código Orgánico de Tribunales, respectivamente. (...) El de queja se limita porque entendemos que, siendo éste un recurso disciplinario, ha distorsionado en la práctica el sistema procesal y la función jurisdiccional de los Tribunales Superiores de Justicia, toda vez que se interpone en vez de otros recursos procedentes, recargando el trabajo de las Cortes, dándose el caso que por esa vía la Corte Suprema pueda llegar a conocer de cualquier causa que se tramita en primera instancia. Estos recursos son fallados sin consignarse los fundamentos de las resoluciones y sin que sea escuchada la contraparte en el pleito, rompiéndose así el principio de bilateralidad de la audiencia ${ }^{57}$.

Fruto de esta reforma, se modificó, tal cual se indicó en el mensaje, el artículo 545 del Código Orgánico de Tribunales (COT), el cual quedó redactado de la siguiente manera:

El recurso de queja tiene por exclusiva finalidad corregir las faltas o abusos graves cometidos en la dictación de resoluciones de carácter jurisdiccional. Sólo procederá cuando la falta o abuso se cometa en sentencia interlocutoria que ponga fin al juicio o haga imposible su continuación o definitiva, y que no sea susceptible de recurso alguno, ordinario o extraordinario, sin perjuicio de la facultad de la atribución de la Corte Suprema para actuar de oficio en ejercicio de sus facultades disciplinarias $[\ldots]$.

La reforma de 1995 alteró la circunstancia que precisamente había permitido la proliferación de este recurso, disponiendo — entre otras importantes restricciones- que el recurso sólo procederá cuando la falta o abuso se cometa en una sentencia interlocutoria que ponga fin al juicio o haga imposible su continuación, o en una sentencia definitiva. Esta última alteración fue particularmente nefasta para la materia que estamos analizando.

De este modo, con posterioridad a la referida innovación no se han intentado recursos de queja para impugnar la sentencia condenatoria que niega la concesión de los beneficios de la ley 18.216, y los pocos que se han presentado, rápidamente han sido desechados. Así, por ejemplo, el año 1998 la Corte Suprema señaló:

Que en cuanto a la decisión de las medidas alternativas al cumplimiento efectivo de la pena privativa de libertad, el fallo no tiene el carácter de ser una sentencia definitiva o interlocutoria que ponga término al juicio o haga imposible su continuación. De conformidad, además, con lo dispuesto en

\footnotetext{
${ }^{57}$ Diario de sesiones del Senado, 12 de noviembre de 1992, sesión 10ª ordinaria (anexo documentos), págs. 1015, 1016 y 1017.
} 
los artículos 545 y 549 del COT, se rechaza, por inadmisible, el recurso de queja interpuesto en lo principal de fojas $8^{58}$.

En esta sentencia, si bien la Corte declara inadmisible el recurso de queja, de oficio invalida la sentencia de segunda instancia porque, en su opinión el condenado no reunía los requisitos previstos por el legislador en los artículos 4 y 5 de la ley 18.216 para acceder a la remisión condicional de la pena. Una vez más, por tanto, la Corte siente que debe actuar allí donde los formalismos no se lo permiten.

El 31 de mayo de 2005 resolvió:

Que el artículo 545 del COT indica que el recurso de queja sólo procede respecto de sentencias definitivas o interlocutorias que pongan fin al juicio o hagan imposible su continuación, y que no sean susceptible de recurso alguno, ordinario o extraordinario, naturaleza que no reúne la resolución impugnada, puesto que sólo dice relación con la posibilidad de otorgar beneficios alternativos para el cumplimiento de la pena, materia que no forma parte de la sentencia definitiva, aun cuando se incluya materialmente en ella, por lo que el recurso no debe ser admitido a tramitación. Y visto, además, lo dispuesto en la letra a) del artículo 549 del cuerpo legal mencionado, se declara inadmisible el recurso interpuesto en lo principal de fojas $13^{59}$.

Estos fallos son una buena muestra del excesivo formalismo que ha caracterizado a nuestro sistema judicial. Como puede apreciarse, ahora sí es relevante para la procedencia del recurso de queja la naturaleza de la resolución que se pronuncia sobre las medidas alternativas a la prisión. Y en este punto, la Corte sigue exactamente el mismo razonamiento que durante años utilizó para declarar inadmisibles los recursos de casación, y que actualmente utiliza para desechar el recurso de nulidad: la resolución que se pronuncia sobre estas medidas no es una sentencia definitiva ni una interlocutoria que ponga término al juicio o haga imposible su continuación. Por esas veleidades de la historia los tres recursos terminaron siendo desechados ;con el mismo argumento!

\section{El recurso de nulidad (2000-2007): sigue la senda del recurso de casación y del de queja.}

\footnotetext{
58 Corte Suprema, 13 de agosto de 1998, Rol No 1960-98. Pronunciado por los ministros señores Guillermo Navas, Alberto Chaigneau del C., Enrique Cury U., José Luis Pérez y abogado integrante Vivian Bullemore G.

59 Corte Suprema, 31 de mayo de 2005, Rol No 1782-05. Pronunciado por la Segunda Sala integrada por los ministros señores. Nibaldo Segura P., Adalis Oyarzún M., Jaime Rodríguez E., y los abogados integrantes señores Fernando Castro A. y Emilio Pfeffer P.
} 
REJ - Revista de Estudios de la Justicia - No 10 - Año 2008

4.1. Recurso de nulidad. (2000-2007). A pesar de los pocos años de vigencia del Código Procesal Penal, existen algunos fallos relativos a recursos de nulidad que se han pronunciado sobre esta materia. Como el lector atento sabe, la mayor parte de estos recursos han sido desechados por las mismas razones que vimos sirvieron para justificar la inadmisibilidad del recurso de casación. Así, el 8 de julio de 2004 la Corte Suprema, conociendo de un recurso de nulidad, en contra de la resolución del tribunal del juicio oral en lo penal de Antofagasta, que condenó al imputado por el delito de robo con fuerza en las cosas, y no le concedió ninguno de los beneficios alternativos establecidos en la ley 18.216, y le revocó otro que se le había concedido en una anterior condena, señaló:

«Que bajo la misma causal de nulidad del art. 373 letra b) del Código Procesal Penal se sostiene que se ha infringido también el art. 26 de la ley $\mathrm{N}^{\mathrm{o}} 18.276$ al revocarse el beneficio que se le había concedido a [...] por la anterior sentencia condenatoria de que había sido objeto, porque no se cumplirían los supuestos que la norma exige para que se puedan revocar los beneficios concedidos al condenado, pues al momento de cometerse el delito frustrado de autos, no estaba el autor condenado en ninguna causa.

Que como se ha fallado reiteradamente, las cuestiones relativas a estos beneficios alternativos no constituyen sentencia definitiva, por más que se contengan en ella, razón por la cual no puede acogerse el recurso de nulidad en esta parte, ya que según el artículo 372 el recurso de nulidad se concede para invalidar el juicio oral y la sentencia definitiva, o solamente ésta, y no abarca por ende aquel otro aspecto» ${ }^{60}$.

El mismo año 2004 (6 de diciembre), en la causa rol Nº 5.097 se expresó que:

«Conforme lo dispone el artículo 372 del Código Procesal Penal, el recurso de nulidad se concede para invalidar el juicio oral y la sentencia definitiva, o solamente ésta, por las causales expresamente señaladas en la ley. En consecuencia, el recurso intentado por el sentenciado no puede admitirse, en atención a la naturaleza de la resolución recurrida: en efecto, si bien las cuestiones relativas a beneficios alternativos se resuelven y consignan materialmente en la sentencia condenatoria, no participan del carácter de sentencias definitivas, puesto que no resuelven el asunto que ha sido objeto del juicio, siendo entonces improcedente el recurso».

El año 2005 (21 de septiembre) nuestro máximo tribunal tuvo otra vez la oportunidad de pronunciarse sobre esta materia. Una vez más resolvió:

60 Corte Suprema, Rol No 1.985-2004. Pronunciado por la Segunda Sala integrada por los Ministros señores Enrique Cury U., Nibaldo Segura P., Jaime Rodríguez E.; y los abogados integrantes señores René Abeliuk M. y Luz María Jordán. Lexis Nexis No de identificador 30.429. 
«Que, la defensa del sentenciado [...] ha recurrido de nulidad en contra del fallo que lo condenó como autor de robo con fuerza en lugar destinado a la habitación a la pena de 800 días de presidio menor en su grado medio, accesorias y costas, sin concederle ninguno de los beneficios previstos en la ley 18.216, lo que a su juicio infringe principios de rango constitucional, como es la igualdad ante la ley, por lo que pide se anule la sentencia y se dicte una de reemplazo en la cual se otorgue a [...] el beneficio de la remisión condicional de la pena establecido en la ley 18.216.

Que, conforme lo dispone el artículo 372 del Código Procesal Penal, el recurso de nulidad se concede para invalidar el juicio oral y la sentencia definitiva, o solamente ésta, por las causales expresamente señaladas en la ley. En consecuencia, el recurso intentado por el sentenciado no puede admitirse, en atención a la naturaleza de la resolución recurrida: en efecto, si bien las cuestiones relativas a beneficios alternativos se resuelven y consignan materialmente en la sentencia condenatoria, no participan del carácter de sentencias definitivas, puesto que no resuelven el asunto que ha sido objeto del juicio, siendo entonces improcedente el recurso» ${ }^{61}$.

El 30 de marzo de 2006 la Corte de Apelaciones de Santiago, conociendo un recurso de nulidad presentado en contra de la resolución de un juez de garantía, que condenó al acusado en un procedimiento simplificado, y en el cual no concedió ninguno de los beneficios regulados en la ley 18.216, rechazó dicho recurso, teniendo presente, entre otras razones, que:

«Además no puede olvidarse que si bien esta clase de resoluciones se adopta en la sentencia no forman parte de ella, puesto que no dice relación con la acusación, que es la actuación que determina el objeto del juicio. Tal criterio, a propósito de resoluciones dictadas en los procedimientos del Código de Procedimiento Penal, es el que reiteradamente ha sido sostenida por la jurisprudencia» ${ }^{62}$.

El 11 de abril de 2006 la Corte Suprema ratificó toda su doctrina. Ese día resolvió que:

Conforme lo dispone el artículo 372 del Código Procesal Penal, el recurso de nulidad se concede para invalidar el juicio oral y la sentencia definitiva, o solamente ésta, por las causales expresamente señaladas en la ley. En consecuencia, el recurso intentado por el sentenciado no puede admitirse,

61 Corte Suprema, Rol N ${ }^{\circ}$ 4.243-2005. Pronunciado por la Segunda Sala integrada por los Ministros señores Nibaldo Segura P., Adalis Oyarzún M., Rubén Ballesteros C., y los abogados integrantes señores Manuel Daniel A. y José Fernández. Lexis Nexis $\mathrm{N}^{\circ}$ de identificador 32.950. En el mismo sentido véase Corte Suprema Rol No 3.719-2005, 23 de agosto de 2005, Lexis Nexis $\mathrm{N}^{\circ}$ de identificador 32.591.

${ }^{62}$ Rol 342-2006. Lexis Nexis $\mathrm{N}^{\circ}$ de identificador 34.083. 
REJ - Revista de Estudios de la Justicia - No 10 - Año 2008

en atención a la naturaleza de la resolución recurrida: en efecto, si bien las cuestiones relativas a beneficios alternativos se resuelven y consignan materialmente en la sentencia condenatoria, no participan del carácter de sentencias definitivas, puesto que no resuelven el asunto que ha sido objeto del juicio, siendo entonces improcedente el recurso. Y vistos, además, lo dispuesto en los artículos 380 y 383 del Código Procesal Penal, se declara inadmisible el recurso de nulidad ${ }^{63}$.

4.2. Se impone una nueva interpretación. En este trabajo hemos visto que la estricta interpretación que se generó a propósito del recurso de casación, se extendió sin mayor cuestionamiento después del año 1995 al recurso de queja, y,

${ }^{63}$ Corte Suprema, Rol No 1.341-06. Pronunciado por la Segunda Sala integrada por los Ministros Sres. Alberto Chaigneau del C., Enrique Cury U., Nibaldo Segura P., Jaime Rodríguez E. y Rubén Ballesteros C. Lexis Nexis $\mathrm{N}^{\circ}$ de identificador 34.056. El 03 de noviembre de 2006, la Corte de Apelaciones de Punta Arenas, tratándose de un procedimiento simplificado también desechó el recurso de nulidad intentado. En esta oportunidad señaló el tribunal de alzada: "Que se ha invocado como causal de nulidad absoluta del juicio y de la sentencia la contemplada en la letra e) del artículo 374, en relación con el artículo 342 letra c), ambas del Código Procesal Penal, esto es cuando en el fallo se ha omitido la exposición clara, lógica y completa de cada uno de los hechos y circunstancias que se dieren por probados, fueren ellos favorables o desfavorables al acusado, y de la valoración de los medios de prueba que fundamentaren dichas conclusiones de acuerdo con lo dispuesto en el artículo 297 del mismo texto legal; $2^{\circ}$.- Que sostiene el recurrente que concurre esta causal toda vez que estima que el sentenciador no fundamentó debidamente su resolución negativa en cuanto a suspender a su defendido el cumplimiento de la medida alternativa de las penas privativas de libertad de la reclusión nocturna que le fuere otorgado en la sentencia condenatoria y, además no emitió pronunciamiento sobre la solicitud de esa defensa en cuanto a decretar el arresto domiciliario nocturno, en los términos a que alude el artículo $7^{\circ}$ de la ley 18.216 , establecido en la letra a) del artículo 10 de la misma. Solicita se anule el juicio y la sentencia recurrida y se determine el estado en que hubiere de quedar el procedimiento; $3^{\circ}$.- Que tratándose en la especie de una sentencia dictada en un juicio simplificado en que, conforme a lo dispuesto en el artículo 395 del Código Procesal Penal, habiendo el imputado admitido responsabilidad en los hechos contenidos en el requerimiento, y renunciado a solicitar la realización de la audiencia, contemplada en el artículo 396 del mismo código, en la que es posible recibir prueba, se procedió a dictar la sentencia de inmediato; $4^{\circ}$.- Que, en consecuencia, resulta improcedente exigir al sentenciador que su fallo contenga una exposición clara, lógica y completa de cada uno de los hechos y circunstancias que se dieren por probados, fueren ellos favorables o desfavorables al acusado, y de la valoración de los medios de prueba que fundamentaren dichas conclusiones, como lo sostiene el recurrente, toda vez que como se desprende de lo expresado, no se ha rendido probanza alguna que deba ser apreciada conforme a esa norma; $5^{\circ}$.- Que, por otra parte, del examen del fallo recurrido se deduce que el sentenciador cumplió con la exigencia que le impone el artículo 348 del Código Procesal Penal en cuanto a pronunciarse sobre la eventual aplicación de alguna de las medidas alternativas a la privación o restricción de libertad previstas en la ley, y siendo éstas de aplicación facultativa para el Juez, no se puede sostener que haya incurrido en causal de nulidad al no acceder a su aplicación en la forma solicitada por la defensa, razones todas por las cuales no puede prosperar el presente recurso». Rol 139-2006. Lexis Nexis $\mathrm{N}^{\circ}$ de identificador 35.405 . 
en la actualidad, al novel recurso de nulidad. Pero, ¿existe tal simetría entre estos recursos como para justificar esta situación? Lógicamente lo ocurrido al recurso de queja se explica porque el legislador buscó reducirlo a una mínima expresión, por ello lo hizo incompatible con los demás recursos previstos en el ordenamiento procesal. Pero tratándose del recurso de nulidad ¿era esta una situación esperable y, lo más difícil, justificable? Creo que no. Lo más sorprendente ha sido que los jueces parecen no reparar bien en algunas disposiciones del Código Procesal Penal que aportan buenos argumentos para revisar la que ha sido esta tradicional visión. Queda la sensación en esta materia de cierto autismo legal por parte de nuestros tribunales, que no desean ver más allá de lo establecido a propósito de un sistema criminal totalmente diverso.

No sólo la ley 18.216 ya había mejorado la redacción de la ley 7.821, como latamente lo hemos explicado en este trabajo, sino que el artículo 348 del Código Procesal Penal, que trata precisamente de la sentencia condenatoria, expresa en su inciso primero que la «sentencia condenatoria fijará las penas y se pronunciará sobre la eventual aplicación de alguna de las medidas alternativas a la privación o restricción de libertad».

Es muy difícil entender con este claro tenor literal, que los jueces sigan sosteniendo que la sentencia que se pronuncia sobre las medidas de la ley 18.216 si bien integra la sentencia definitiva, no forman parte de ella. Pero, ¿qué otra cosa puede ser sino una sentencia definitiva aquella parte de la sentencia definitiva que se pronuncia sobre la manera cómo se cumplirá la pena? ${ }^{64}$

El propio artículo 343 del CPP, sobre la decisión de absolución o condena, precisamente obliga al tribunal del juicio oral en lo penal a abrir debate sobre los demás factores relevantes para la determinación y cumplimiento de la pena en la misma audiencia en que se pronuncia la condena. Si esta circunstancia fuere omitida, ¿no sería anulable esta sentencia? O se va argumentar también que no estamos frente a una sentencia definitiva y, por tanto, que no es procedente el recurso de nulidad.

El argumento según el cual la resolución que se pronuncia sobre alguno de los beneficios establecidos en la ley 18.216, no forma parte de la sentencia definitiva aunque materialmente allí se contenga, obedece a una larga tradición de

\footnotetext{
64 Esto me recuerda una graciosa anécdota referida por Calamandrei, a propósito de la tutela cautelar, pero que muestra muy bien la perplejidad con la cual uno queda frente a determinado tipo de argumentación judicial. En la discusión de qué debemos englobar bajo la denominación de medidas cautelares, y frente a la insistencia de cierta doctrina de no reconocer dicho carácter a determinada figura jurídica, Calamandrei trae a colación «la respuesta dada por aquel examinado que, interrogado acerca de la cuestión homérica, y puesto entre la espada y la pared al preguntarle, si, en definitiva, Homero era o no era el autor de la Ilíada y de la Odisea, respondió: "Homero, no; sino un coterráneo suyo que vivió por los mismos años y que llevaba su mismo nombre"» Introducción al estudio sistemático de las providencias cautelares, Buenos Aires, 1945, pág. 60.
} 
REJ - Revista de Estudios de la Justicia - No 10 - Año 2008

nuestra Corte Suprema que, durante años, se ha construido a propósito de la tramitación de algunos incidentes cuya resolución se deja para definitiva. Paradigmático, en este sentido, es el relativo a las tachas de los testigos que, como se sabe, por disposición expresa de ley deben resolverse en la sentencia definitiva.

$\mathrm{Al}$ respecto el artículo 379 del CPC señala lo siguiente: «Las resoluciones que ordenan recibir prueba sobre las tachas opuestas son inapelables. No obstante lo dispuesto en el inciso anterior, la legalidad de las tachas y su comprobación serán apreciadas y resueltas en la sentencia definitiva» ${ }^{65}$.

Más allá de lo dudoso que puede resultar la teoría de la desintegración de la sentencia definitiva, lo que resulta inadmisible es que ella se traslade desde una materia que tiene una expresa previsión legal, a una que no la tiene, y que más bien tiene normas que van en sentido contrario a dicha argumentación.

En mi concepto los jueces por aplicación del artículo 24 de la ley 18.216 deben fundar debidamente el rechazo o la concesión de alguna de las medidas allí previstas —en este último caso incluso en grado de convicción-. Este pronunciamiento integra plenamente el contenido de la sentencia condenatoria (artículo 348 del CPP), situación sobre la cual se debe abrir debate para que la

${ }^{65}$ Un buen resumen de esta doctrina lo encontramos en el Repertorio de Legislación y Jurisprudencia a propósito del artículo 158 del CPC: «No puede darse el nombre de definitivas a las resoluciones que, incorporadas dentro de la sentencia final, resuelven, junto con la cuestión de fondo controvertida, las peticiones procesales de las partes. La oportunidad en que se dicta una resolución cualquiera no es factor determinante de su calificación. Existen casos en que en un mismo juicio se deducen peticiones de fondo, como son la acción y acciones entabladas por el actor, las excepciones perentorias, o, en general, las defensas opuestas por el demandado encaminadas a enervar en definitiva el derecho del demandante; y en que, además, de esas peticiones tocantes al fondo de la cuestión debatida, se formulan, conjuntamente con ellas, peticiones de carácter procesal, como ocurre con las tachas contra los testigos reservadas para definitiva, con la impugnación de documentos, etc. Admitiendo la teoría de la desintegración de la sentencia final en resoluciones parciales, es posible distinguir en aquélla: la sentencia definitiva misma, que como tal debe calificarse la resolución que decida la cuestión de fondo controvertida; sentencias interlocutorias, que no otro nombre deben tomar las resoluciones que, en definitiva, fallen incidentes de aquéllos que crean derechos permanentes a favor de las partes; y aun, autos, como debe calificarse la resolución definitiva en cuanto decida, en dicha oportunidad, derechos nacidos en función de la sentencia, que deben ser fallados por simples autos; y así sucesivamente. No todo lo reservado para definitiva es materia que forzosamente debe ser resuelta en sentencia final. Las peticiones sometidas a las decisiones de los tribunales son de fondo o procesales, no por el lugar o ubicación que ocupan dentro del proceso, sino según la naturaleza de la cosa pedida, que es la que imprime su fisonomía y caracteriza a las resoluciones que en ella recaigan. De modo que es perfectamente procedente hacer la disgregación de una sentencia final y distinguir en ella la sentencia definitiva propiamente tal y las resoluciones incidentales, que pueden ser interlocutorias o autos, según se trate de resolver la cuestión de fondo o peticiones de índole meramente procesal». Se citan entre otras: RDJ, año VII (1910), $2^{a}$. parte, sección primera, págs. 505-538; RDJ, t. XXIX (1931), 2a . parte, sección primera, págs. 173-176; y RDJ, t. LVI (1959), 2a . parte, sección cuarta, págs. 104-107 
defensa (también el fiscal) pueda aportar todos los antecedentes que muestren si debe o no concederse alguna de dichas medidas (artículo 343 del CPP). Esta no es una prerrogativa graciosa del condenado, sino un derecho que los jueces deben otorgar o denegar fundadamente. De allí que la infracción de estas normas legales constituye una errónea aplicación del derecho produciendo un motivo absoluto de nulidad (artículo 374 letra e) en relación con el artículo 342 letra c) y, por tanto, hace procedente el recurso de nulidad, como lo sostuvo la Corte de San Miguel el 5 de mayo de 2006:

Que el artículo 374 del Código Procesal Penal, señala que serán siempre anulados el juicio y la sentencia: e) cuando en la sentencia, se hubiere omitido alguno de los requisitos previstos en el artículo 342 letra c), lo que acontece en la especie en que no se hizo valoración de los medios de prueba — de acuerdo a lo dispuesto en el artículo 297 del mismo códigoen que el tribunal fundamentó su negativa a conceder al condenado el beneficio de la libertad vigilada (...). La sentencia cuya nulidad se pretende, sobre el punto que nos estamos refiriendo, no expone cuáles son las graves razones, que el denominado informe presentencial contiene las que sólo sabemos - no han logrado ser desvirtuadas por los dichos de los testigos [...] y que hacen concluir a los sentenciadores del juicio oral, que el condenado no es merecedor del beneficio alternativo que su defensa pide para el cumplimiento de la pena privativa de libertad que le impone $^{66}$.

Resulta un contrasentido que la decisión sobre la aplicación de las medidas alternativas no pueda ser impugnada. Esta situación se debió a una conjunción desafortunada de dos circunstancias diversas, según lo hemos mostrado a lo largo de este trabajo. Nadie ha pretendido que las medidas allí reguladas queden sin control del tribunal superior. La circunstancia de que el legislador precisamente haya previsto que la sentencia condenatoria que se pronuncia sobre la aplicación de alguna de estas medidas alternativas, debe ser fundada muestra que inequívocamente su intención ha sido que esta fundamentación sea susceptible de revisión.

En este punto se impone volver sobre los primeros fallos de nuestra Corte Suprema. Hay que volver sobre la idea que, al determinar la manera cómo debe cumplirse lo fallado, no hay una decisión ajena a la cuestión que fue materia del proceso y mucho menos que se resuelva un incidente relativo a puntos inconexos con los que fueron materia de la acusación y de la defensa. Que no se está frente a una facultad graciosa de nuestros tribunales, sino frente a un derecho de los condenados. Como dijo nuestro máximo tribunal el año 1959: «Todo lo relativo al beneficio se incorpora íntegramente a la sentencia, y forma con ella un solo todo consubstancial. No se introduce, por este suceso, una cuestión accesoria o

\footnotetext{
${ }^{66}$ San Miguel, 5 de mayo de 2006, Rol 338-2006.
} 
REJ - Revista de Estudios de la Justicia - No 10 - Año 2008

independiente, toda vez que el reo adquiere una situación de trascendencia, ligada a la condena, dado que la pena privativa de libertad queda expuesta a mantenerse en suspenso» y hasta puede desaparecer si se cumplen con los requisitos sancionados en la ley 18.216. 